\title{
ENFRENTAMENTO AOS IMPACTOS DA COVID-19: GOVERNOS LIDERADOS POR MULHERES APRESENTAM MELHOR RESPOSTA EM PREVENÇÃO A PANDEMIA?
}

\section{FACING THE IMPACTS OF COVID-19: DO WOMEN-LED GOVERNMENTS HAVE A BETTER RESPONSE IN PREVENTING THE PANDEMIC?}

\author{
SARAH AMARAL FABRÍCIO \\ Mestranda em Contabilidade \\ Universidade Federal de Santa Catarina (UFSC) \\ Orcid: https://orcid.org/0000-0002-5078-8743 \\ E-mail: sarahamaralfabricio@gmail.com \\ Campus Universitário Reitor João David Ferreira Lima, s/no, Trindade - Florianópolis/SC - Brasil - \\ CEP: $88040-900$
}

\section{DENIZE DEMARCHE MINATTI FERREIRA}

Doutora em Engenharia e Gestão do Conhecimento (UFSC)

Professora Titular da Universidade Federal de Santa Catarina (UFSC)

Orcid: https://orcid.org/0000-0002-4661-9672

E-mail: denize.minatti@ufsc.br

\section{JOSÉ ALONSO BORBA}

Doutor em Controladoria e Contabilidade - Universidade de São Paulo (USP)

Professor Titular da Universidade Federal de Santa Catarina (UFSC)

Orcid: https://orcid.org/0000-0001-6068-342X

E-mail: j.alonso@ufsc.br

\begin{abstract}
Submissão: 15/08/2020. Revisão: 02/11/2020. Aceite: 26/11/2020. Publicação: 29/12/2020.
DOI: http://dx.doi.org/10.22277/rgo.v14i1.5754
\end{abstract}

\section{RESUMO}

A partir do fim de 2019 teve início o surto de COVID-19, a epidemia, com epicentro em Wuhan, na China, que até então afetou mais de 56 milhões de pessoas no mundo. Desde o início, se constatou que determinados países mostravam respostas mais positivas no combate à doença e se percebeu que alguns deles eram liderados por mulheres, como a Nova Zelândia, a Noruega, a Dinamarca, a Alemanha, dentre outros. Assim, o artigo tem como objetivo, comparar as práticas de prevenção à COVID-19 em países liderados por mulheres. Quanto à metodologia, a pesquisa é descritiva e a coleta de dados foi feita por meio de pesquisa documental e a amostra consiste nos 30 países com maior Índice de Desenvolvimento Humano (IDH) do mundo e o Brasil, por ser um dos países mais afetados pela doença. Os resultados sugerem que dos 31 países da amostra, entre os 10 com menores números absolutos de casos de COVID-19, 5 deles são governados por mulheres: Nova Zelândia, Hong Kong, Grécia, Estônia e Islândia. Dos 10 países com menor contágio, 4 deles são liderados por mulheres: Hong Kong, Nova Zelândia, Grécia e Estônia. Presume-se então que as líderes mundiais do gênero feminino parecem ter realizado melhor trabalho de enfrentamento contra a COVID-19.

Palavras-chave: COVID-19. Mulheres. Governos. Gênero. Prevenção. 
Enfrentamento aos impactos da COVID-19:

governos liderados por mulheres apresentam melhor resposta em prevenção a pandemia?

\section{ABSTRACT}

The COVID-19 outbreak began at the end of 2019, the epidemic, with its epicenter in Wuhan, China, affected more than 56 million people around the world. From the beginning, it was observed that certain countries showed better responses in countering the disease, and some of them were headed by women, such as New Zealand, Norway, Denmark, Germany, among others. Thus, the article aims to compare prevention practices against COVID-19 in countries governed by women. The methodology is descriptive, and data were collected through documental research, the sample consists on the 30 countries with the highest Human Development Index (HDI) in the world, and Brazil, as one of the countries most affected by the disease. The results suggest that of the 31 countries in the sample, among the 10 with the lowest absolute numbers of COVID-19 cases, 5 of them are governed by women: New Zealand, Hong Kong, Greece, Estonia, and Iceland. Of the 10 countries with the lowest number of cases of COVID-19, 4 are led by women: Hong Kong, New Zealand, Greece, and Estonia. Hence, it is assumed that women world leaders seem to have done a better job at confronting COVID-19.

Keywords: COVID-19. Women. Governments. Gender. Prevention.

\section{INTRODUÇÃO}

No final de 2019 se iniciou o surto da COVID-19, a epidemia, com epicentro em Wuhan, na China, afetou mais de 56.623 .643 de pessoas no mundo, com registro de pelo menos 1.355.963 mortes confirmadas em 188 países, até 20 de novembro de 2020 (OPAS, 2020). Inicialmente a cidade e suas proximidades foram fechadas com a finalidade de se tentar conter o que hoje é uma pandemia.

A doença se espalhou para países vizinhos e alcançou praticamente o mundo todo. Segundo Anderson et al. (2020), os governos não serão capazes de minimizar as mortes por doença causada pelo Coronavírus 2019 (COVID-19) e o impacto econômico da propagação viral. Os autores afirmam que manter a menor mortalidade possível será a maior prioridade para a sociedade; portanto, os governos devem adotar medidas para melhorar a inevitável crise de saúde pública e, por conseguinte, econômica.

Desde o dia 11 de março de 2020, vive-se um período de reconfiguração social a partir da declaração do Coronavírus como uma pandemia pela Organização Mundial da Saúde (OMS). A partir de então, para enfrentar essa crise, medidas como isolamento social, quarentena e lockdown têm sido tomadas alterando profundamente as dinâmicas sociais e econômicas.

Conforme notícias veiculadas na mídia nacional e internacional, muitas chamadas sobre o Coronavírus apresentavam o quanto os países com líderes mulheres mostravam ser superiores no enfrentamento da doença. As mulheres representam $70 \%$ dos profissionais de saúde em todo o mundo e no mundo político, em 2018, eram apenas dez dos 153 chefes de Estado eleitos, de acordo com a União Interparlamentar (UCHOA, 2020).

De acordo com Queiroz (2020), ao longo de todo o século XX foram muitas conquistas em termos de direitos alcançados pelas mulheres, no entanto, persistem ainda nos costumes e imaginário social, responsabilidades e condições que fazem com que o trabalho feminino ocorra no bojo de contradições explícitas: diferenças salariais entre homens e mulheres nas mesmas funções; poucas mulheres em cargos de gestão e chefia corporativa; oportunidades menores de inserção no mercado quando comparado aos homens. 
As mulheres foram sub-representadas também na pandemia desde o início do surto. Gênero, igualdade e inclusão são fundamentais para se ter sucesso na luta global contra a doença e a contribuição desproporcional das mulheres, por exemplo, as pesquisas sobre a COVID-19 refletem um viés de gênero mais amplo na ciência que deve ser abordado (FARIZA, 2020).

Isto é especialmente verdade, pois há diferenças de sexo e gênero nas taxas de mortalidade e no longo prazo econômico e social da COVID-19, apontando um futuro equilíbrio na perspectiva de gênero cada vez mais importante (OCDE, 2020). É necessário prover solução possível para superar a baixa representação de mulheres persistente em diferentes setores da sociedade. Um passo adicional seria considerar cotas de gênero, para ajudar a corrigir a sub-representação das mulheres em posições de destaque, por exemplo, em sistemas político, econômico e acadêmico.

Dollar et al. (2001) sugerem que as mulheres devem ser particularmente eficazes na promoção de um governo honesto e mais justo. Atkeson e Carrillo (2007) apontam que maiores níveis de representação feminina nos governos promovem valores mais elevados de eficácia externa, sugerindo benefícios importantes para uma sociedade democrática. Diante dos fatos expostos, o artigo tem como objetivo, comparar as práticas de prevenção à COVID19 em países liderados por mulheres e por homens e visa responder à pergunta: Os países liderados por mulheres apresentam melhores resultados no enfrentamento contra a COVID19 do que países liderados por homens?

A pesquisa se justifica pela importância de se estudar as mulheres nas lideranças, visto que a igualdade de gênero ainda não foi atingida em muitas sociedades atuais (CUNHA; SPANHOL, 2014). E, principalmente por auxiliar os países a verificarem o que está sendo feito adequadamente no enfrentamento da pandemia e, especificamente, no que se refere ao combate à COVID-19.

Estudos nessa linha são necessários uma vez que as respostas à pandemia da COVID19 não foram suficientemente consideradas em relação ao gênero, logo são fundamentais políticas que incluam mulheres na tomada de decisões sobre os assuntos que afetem a sociedade. Outrossim, compreender até que ponto a COVID-19 afetou mulheres e homens de maneira diferente será fundamental para entender o impacto mais amplo desta doença durante a crise e na recuperação individual e social (MCLAREN et al., 2020).

A pesquisa se justifica também pela importância de se discutir questões de gênero nos diversos setores, como por exemplo, na política, e visa entender os motivos relacionados a baixa representatividade feminina em cargos políticos ou de governança pública. Segundo Nova (2012), isso pode acontecer devido à fenômenos praticamente invisíveis chamados de: critical mass, role model, glass ceilling ou pipeline, que podem diminuir a presença de mulheres em diferentes áreas. Estes fenômenos também ocorrem na esfera política, onde a ampliação da discussão destas problemáticas podem vir a auxiliar a conscientização dessas dificuldades e a inserção de políticas de apoio às mulheres na política.

O estudo das respostas das políticas à COVID-19 pode ajudar a entender como construir sociedades adequadas no futuro, especialmente graças à heterogeneidade de resultados, o que pode ajudar esclarecer quais ações e fatores estruturais são mais significativos na determinação do sucesso em lidar com crises de saúde (COSCIEME et al., 2020). Além disso, é necessário que se estude sobre o gênero na pandemia, visto que segundo OCDE (2020), a pandemia do COVID-19 representa uma grave ameaça para a realização dos Objetivos de Desenvolvimento Sustentável (ODS) relacionados ao gênero. Isso prejudica algumas das melhorias observadas desde 2015 em vários aspectos da igualdade de gênero e 
Enfrentamento aos impactos da COVID-19:

governos liderados por mulheres apresentam melhor resposta em prevenção a pandemia?

empoderamento das mulheres. As consequências econômicas e sociais da crise irão exacerbar as desigualdades e a discriminação existentes contra mulheres e meninas, especialmente contra os mais marginalizados e aqueles em extrema pobreza. $O$ desenvolvimento do surto também pode travar algumas políticas e reformas de transformação de gênero, desviando recursos das necessidades passadas e atuais das mulheres, ao passo que a crise na verdade as aumentará e expandirá (OCDE, 2020).

\section{REFERENCIAL TEÓRICO}

A COVID-19 está revolucionando o mundo como o conhecíamos, poucos aspectos da vida foram imunes aos seus efeitos, já que os governos fecharam sociedades, partes da economia e restringiram a liberdade do movimento de bilhões de pessoas em todo o mundo (SHARLAND, 2020). O autor ainda afirma que embora o próprio vírus não discrimine, as respostas traduzidas em políticas que foram criadas para conter a disseminação continuarão a ter um impacto desproporcional em muitos segmentos da população relacionados ao local onde as pessoas vivem, seu acesso à habitação, saúde e saneamento e emprego. Consequentemente, os esforços para resolver o problema pode exacerbar desigualdades préexistentes em todo o mundo, particularmente para as mulheres.

A significativa sub-representação das mulheres nas posições de liderança tem colocado o tema da diversidade de gênero no centro de análises e debates nos últimos anos. Apesar de algumas melhorias e das crescentes iniciativas para combater a situação, o não aproveitamento das competências de mulheres cada vez mais qualificadas, continua a constituir uma perda de talento e de potencial de crescimento econômico (RODRIGUES, 2017). O mesmo autor lembra que ao longo da história, os homens têm se beneficiado de uma supremacia relativa, entretanto, dependendo do país, há alterações e muitas delas devido aos movimentos feministas que alertavam para a existência de desigualdades, e que reivindicavam de direitos legais nas áreas da participação política, da educação e de acesso ao mundo do trabalho pelas mulheres.

Com raízes na década de 1980, o empoderamento das mulheres é agora uma preocupação predominante na sociedade (CORNWALL, 2016). Para o mesmo autor é fundamental considerar os ganhos - o que as mulheres podem fazer pelo desenvolvimento, ao invés de que o desenvolvimento pode fazer pelas mulheres?

Para Ceribeli et al. (2017) são necessárias ações afirmativas que preparem e promovam indivíduos do gênero feminino a cargos de chefia o que pode representar um caminho para romper com a resistência apresentada à ascensão profissional das mulheres.

Países da Europa, Ásia e África implementaram formas de mandato e/ou metas para se determinar a porcentagem de mulheres nos conselhos, tendência que iniciou após a Noruega introduzir, em 2006, exigência de pelo menos $40 \%$ dos assentos de seus conselhos ocupados por elas. A União Europeia e o estado da Califórnia nos EUA propuseram regulamentos especificando um número fixo de mulheres como membros dos Conselhos de Administração (CHARUMATHI; RAHMAN, 2019). É uma realidade a inserção das mulheres cada vez maior nas empresas, porém nota-se que elas dificilmente ocupam cargos de alta gerência. Lima et al. (2018) verificaram que nas carreiras de auditoria, por exemplo, elas ocupam níveis hierárquicos mais baixos, enquanto os homens estão em cargos que mais se aproximam ou estão na posição de sócio.

Quanto ao papel da mulher no combate à COVID-19, segundo OCDE (2020), as mulheres são em torno de $70 \%$ da força de trabalho na área da saúde, expondo-os a um maior 
risco de infecção. Ao mesmo tempo, as mulheres também estão arcando com a maior parte (ou o total delas) das tarefas domésticas, dado o fechamento de escolas e creches e com as desigualdades de gênero no trabalho não remunerado. As mulheres também enfrentam, e maiores riscos de violência, exploração, abuso ou assédio durante tempos de crise e quarentena.

Piazza e Diaz (2020) argumentam que a pandemia da COVID-19 de 2019-2020 pode ter um potencial de produzir um resultado favorável para as mulheres. Pesquisas de opinião pública recentes destacam o descontentamento com a forma como os políticos administraram a pandemia e as preocupações generalizadas em torno da "questão das mulheres" na saúde pública. Os autores ainda complementam que os recentes relatos positivos da mídia sobre as respostas de mulheres líderes mundiais à pandemia fornecem razões para suspeitar de um futuro aumento no apoio político às candidatas.

Eventos que incluem fome, guerra, desastres naturais ou surtos de doenças estão todos documentados como o aumento da vulnerabilidade das mulheres ao agravamento dos "fardos de gênero" (MCLAREN et al., 2020). Os autores afirmam que no caso da pandemia da COVID-19, não é diferente, embora os "fardos de gênero" estejam bem estabelecidos, a análise nos primeiros meses da pandemia indica que as atribuições das mulheres estão aumentando e estimam que sofrerão agravamento até que a pandemia esteja sob controle e por muito tempo.

Meagher et al. (2020) averiguaram a importância das mulheres em tempos de pandemias, concluindo que uma maior diversidade e liderança com equilíbrio de gênero é um requisito essencial em governos e em organizações multilaterais no desenvolvimento de preparação e respostas para pandemia. Para os autores, cultivar e ampliar intencionalmente a liderança feminina é fundamental para a criação de modelos de liderança eficazes e respostas inclusivas de gênero para melhorar os resultados para as populações vulneráveis em ambientes de conflito.

Para De Paz et al. (2020), as experiências com pandemias anteriores mostraram que essas crises costumam afetar homens e mulheres de maneiras diferentes, especificamente, na eficácia das ações políticas e a prevenção de reversões onerosas no progresso alcançado em direção a uma maior igualdade de gênero que dependerá de como as considerações de gênero são refletidas no exame dos impactos potenciais e nas respostas à COVID-19.

A resposta à crise da COVID-19 demonstra que a maioria da sociedade acredita que o bem-estar humano - não o crescimento econômico - deve ser o centro da política. A pandemia expôs regras fundamentais - focar na "produção" em vez da reprodução sustentável da vida humana que desvaloriza o trabalho de cuidado e aqueles que o executam (BAHN, et al., 2020). Os autores afirmam que a sociedade depende do papel que elas desempenham e quando as políticas são formuladas, o campo da economia tem lições valiosas para mitigar as adversidades à medida que os países navegam nas consequências econômicas, logo uma resposta abrangente à crise da COVID-19 deve reconhecer o trabalho das mulheres como parte integrante do sistema econômico que promove o bem-estar humano.

\section{METODOLOGIA}

A presente pesquisa é descritiva e a coleta de dados foi documental em periódicos nacionais e internacionais e, em websites de jornais de notícias tais como: BBC, CNN, Veja, Época Negócios, Exame, G1 e Folha, com o levantamento de fontes referentes à pandemia e o impacto nos países da amostra. A presente pesquisa foi efetuada a partir de jornais, 
Enfrentamento aos impactos da COVID-19:

governos liderados por mulheres apresentam melhor resposta em prevenção a pandemia?

periódicos e eventos relevantes e que em decorrência da pandemia ainda não ter acabado, igualmente algumas publicações provisórias (eventos e congressos) foram utilizadas.

A amostra consiste nos 30 países com maior IDH do mundo e a inclusão do Brasil, que apesar de ter o 75 melhor IDH, se justifica ser considerado, uma vez que é o segundo país com mais casos e mortes pela COVID-19 desde maio de 2020 (VENAGLIA, 2020). Acredita-se que nações com maiores IDHs possam ter melhores respostas no combate ao COVID-19 e assim, traria menores discrepâncias entre os governados por homens ou mulheres. Os países, seus respectivos IDHs e posições, líderes políticos e gênero, o Continente e número de habitantes estão apresentados no Quadro 1.

\begin{tabular}{|c|c|c|c|c|c|c|}
\hline Posição & Países & IDH & Líder Político & Gênero & Continente & Habitantes \\
\hline 1 & Noruega & 0,944 & Erna Solberg & Feminino & Europa & 5.421 .242 \\
\hline 2 & Austrália & 0,935 & Scott Morrison & Masculino & Oceania & 25.499 .881 \\
\hline 3 & Suíça & 0,93 & Walter Thurnherr & Masculino & Europa & 8.654 .618 \\
\hline 4 & Dinamarca & 0,923 & Mette Frederiksen & Feminino & Europa & 5.792 .203 \\
\hline 5 & Países Baixos & 0,922 & Mark Rutte & Masculino & Europa & 17.134 .873 \\
\hline 6 & Alemanha & 0,916 & Angela Merkel & Feminino & Europa & 83.783 .945 \\
\hline 7 & Irlanda & 0,916 & Michael Higgins & Masculino & Europa & 4.937 .796 \\
\hline 8 & EUA & 0,915 & Donald Trump & Masculino & América & 331.002 .647 \\
\hline 9 & Canadá & 0,913 & Justin Trudeau & Masculino & América & 4.822 .233 \\
\hline 10 & Nova Zelândia & 0,913 & Jacinda Arndern & Feminino & Oceania & 37.742 .157 \\
\hline 11 & Singapura & 0,912 & Halimah Yacob & Feminino & Ásia & 5.850 .343 \\
\hline 12 & Hong Kong & 0,91 & Carrie Lam & Feminino & Ásia & 7.496 .988 \\
\hline 13 & Liechtenstein & 0,908 & Otmar Hasler & Masculino & Europa & 38557 \\
\hline 14 & Inglaterra & 0,907 & Boris Johnson & Masculino & Europa & 10.099 .270 \\
\hline 15 & Suécia & 0,907 & Henry Allard & Masculino & Europa & 67.886 .004 \\
\hline 16 & Islândia & 0,899 & Vigdís Finnbogadóttir & Feminino & Europa & 364134 \\
\hline 17 & Coreia do Sul & 0,898 & Moon Jae-in & Masculino & Ásia & 51.269 .183 \\
\hline 18 & Israel & 0,894 & Reuven Rivlin & Masculino & Ásia & 8.655 .541 \\
\hline 19 & Luxemburgo & 0,892 & Xavier Bettel & Masculino & Europa & 625.976 \\
\hline 20 & Japão & 0,891 & Naruhito & Masculino & Ásia & 126.476 .458 \\
\hline 21 & Bélgica & 0,89 & Sophie Wilmès & Feminino & Europa & 11.589 .616 \\
\hline 22 & França & 0,888 & Emmanuel Macron & Masculino & Europa & 65.273 .512 \\
\hline 23 & Áustria & 0,885 & Alexander v. der Bellen & Masculino & Europa & 9.006 .400 \\
\hline 24 & Finlândia & 0,883 & Sauli Niinistö & Masculino & Europa & 5.540 .718 \\
\hline 25 & Eslovênia & 0,88 & Borut Pahor & Masculino & Europa & 2.078 .932 \\
\hline 26 & Espanha & 0,876 & Pedro Sánchez & Masculino & Europa & 46.754 .783 \\
\hline 27 & Itália & 0,873 & Sergio Mattarella & Masculino & Europa & 60.461 .828 \\
\hline 28 & Rep. Tcheca & 0,87 & Miloš Z. Katerina & Masculino & Europa & 10.708 .982 \\
\hline 29 & Grécia & 0,865 & Sakellaropoulou & Feminino & Europa & 10.423 .056 \\
\hline 30 & Estônia & 0,861 & Kersti Kaljulaid & Feminino & Europa & 1.326 .539 \\
\hline 75 & Brasil & 0,755 & Jair Bolsonaro & Masculino & América & 212.559 .409 \\
\hline
\end{tabular}

Fonte: elaborado pelos autores com base nos dados da pesquisa (2020).

Os dados referentes às medidas de prevenção de cada país a partir de notícias publicadas e informações quanto aos casos de contágio e mortes pela COVID-19 ao final dos meses de maio a julho de 2020 foram compilados e a partir destes, foram analisadas as medidas tomadas pelas líderes mundiais do gênero feminino. As taxas de contágio, registros de mortes e de casos a cada milhão de habitantes também foram levados em consideração na presente análise e avaliados. 


\section{RESULTADOS}

\subsection{NÚMEROS DE CASOS DE COVID-19}

Os números absolutos de casos pela COVID-19 foram os dados e a estratégia definidos para a segmentação da amostra em 3 grupos e, se detectou que os menores números de casos estão nos seguintes países: Austrália, Finlândia, Luxemburgo, Grécia, Estônia, Islândia, Eslovênia, Nova Zelândia, Hong Kong e Liechtenstein. Dentre os 10 países mencionados com menos casos da doença, 5 deles são governados por mulheres: Nova Zelândia, Hong Kong, Grécia, Estônia e Islândia.

A Estônia, apesar de apresentar uma população pequena, tem características para ser um significativo epicentro do surto da doença, visto que em uma de suas ilhas, a taxa de contaminação apresentava níveis altos, mas, felizmente não ocorreu como esperado. $O$ que levou os pesquisadores a considerar que no centro de sua transformação tecnológica está a confiança nas instituições públicas e a crença entre os cidadãos estonianos de que todos colherão os frutos do progresso tecnológico (SILASKOVA; TAKAHASHI, 2020).

Alguns países já voltaram ao que parece ser "próximo a realidade" ou estão a caminho de finalizarem suas restrições, um exemplo é a Nova Zelândia em que as autoridades implementaram bloqueio, ainda que o país registrasse 89 casos por dia (JONNES, 2020). A primeira ministra provou confiança ao agir e, dessa forma se mostrou próxima a população, o que pode ter sido um diferencial no combate à doença, outro ponto foi o comprometimento do governo federal, quando Jacinda Ardern e seus ministros reduziram em $20 \%$ dos seus salários por seis meses (EXAME, 2020). Segundo Novelli (2020), a Austrália não iniciou o enfrentamento tão bem quanto a vizinha Nova Zelândia, mas graças aos governadores, conseguiu reverter a tempo os seus casos em números menores que o esperado (Figura 1).

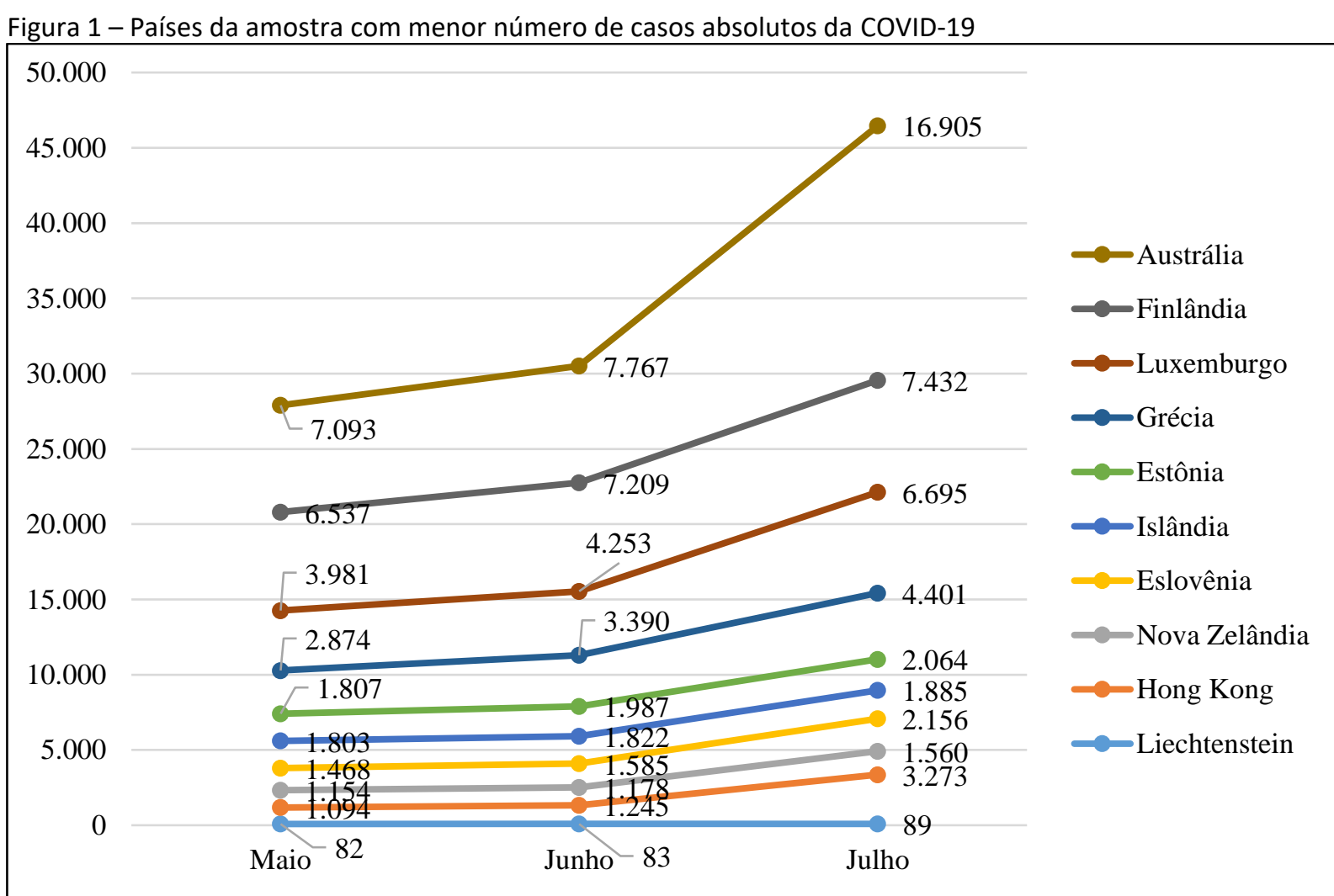

Fonte: elaborado pelos autores com base nos dados da pesquisa (2020). 
Enfrentamento aos impactos da COVID-19:

governos liderados por mulheres apresentam melhor resposta em prevenção a pandemia?

A Finlândia mostrou se preparar para possíveis pandemias, desastres naturais e acontecimento que nenhum país, seus governantes e população deseja se deparar (NACIONAL, 2020). Por sua vez, Liechtenstein é um pequeno país que pareceu utilizar as medidas básicas de prevenção, atualmente já vive uma "certa normalidade" (FOREIGN, 2020). Hong Kong surpreendeu os pesquisadores por figurar entre os países com menor número de casos, devido sua proximidade com a China e alguns pontos foram importantes para a prevenção: experiência com outras síndromes respiratórias, controle de fronteira decisivo e medidas estritas de quarentena, rastreamento de contatos, governo centralizado e hábitos culturais (como o uso de máscaras) (SAIIDI, 2020).

As medidas para proteger o sistema de saúde da Grécia incluíram a criação de um comitê de doenças infecciosas, controles nos aeroportos e portos, informação a população e estreita comunicação com organismos europeus e mundiais de saúde (TUGWELL; NIKAS, 2020). Ao que tange ao andamento da pandemia, a Eslovênia foi o primeiro país europeu a declarar seu fim, porém algumas medidas preventivas continuaram em vigor no país da Europa Central para evitar novas contaminações e uma possível segunda onda (RFI, 2020a).

Apesar de estar entre os países com menor incidência de casos da amostra, Luxemburgo tem um dos maiores números a cada 1 milhão de pessoas e, ao final de março, o país apresentava menores números de registros que a Itália, com uma das maiores taxas de infecção do mundo (WALKER, 2020). Por fim, a Islândia, apesar de ser um país pequeno, apostou em testagem em massa e, graças a um rigoroso regime de isolamento e rastreamento, o país reabriu as fronteiras em 15 de junho (FOSTER; KREVER, 2020).

Os países com números intermediários da amostra são: Suíça, Singapura, Irlanda, Israel, Japão, Áustria, Dinamarca, Coreia do Sul, República Tcheca e Noruega. Dentre estes, apenas 3 são governados por mulheres: Noruega, Dinamarca e Singapura, inclusive, no caso da Noruega, nos últimos números de julho, ela apresentou o menor número de contaminados pelo vírus do que a Austrália (Figura 2). A Noruega foi um dos países que melhor trabalhou no combate à COVID-19, com auxílios aos desempregados, apoio às empresas, impostos adiados e uma participação ativa da líder Erna Solberg (NEGÓCIOS, 2020).

A Coreia do Sul, Japão e Singapura são países próximos do início do surto do vírus, e mesmo assim obtiveram bons resultados. A Coreia contou com número de testes que acompanhou o número de infecções que na Coréia do Sul crescia rapidamente, o que permitiu às autoridades localizar com eficácia os infectados, isolá-los e tratá-los.

A tecnologia foi importante aliada no enfrentamento a pandemia e possibilitou o monitoramento e emissão de alerta às pessoas do contato com caso positivado (BBC, 2020a). Os registros apontam que o Japão não restringiu severamente a população e não realizou testes em massa, embora, o governo central tenha sido criticado por suas medidas políticas lentas. Os especialistas elogiaram o papel dos rastreadores de contato do Japão, que entraram em ação depois que as primeiras infecções foram registradas em janeiro e a resposta rápida foi possibilitada por ser uma das vantagens inerentes ao país - seus centros de saúde pública, que em 2018 empregavam mais da metade dos 50.000 enfermeiros com experiência em rastreamento de infecções (DU; HUANG, 2020).

Singapura, foi considerado exemplo de combate ao vírus, por ser um dos primeiros países a agirem com isolamento social e testagem em massa e quando a gravidade da situação se mostrou evidente mundialmente, os países começaram a solicitar aos seus cidadãos a retornarem ao país. Com isso, muitos que estavam em locais sem barreiras sanitárias, trouxeram o surto de volta ao país (JONES, 2020). 
Figura 2 - Países da amostra com números intermediários de casos absolutos da COVID-19

500.000

50.000

5.000

Fonte: elaborado pelos autores com base nos dados da pesquisa (2020).
35.232

52.205

26.065 —-Suíça

$70.970 \multimap$ Singapura

$36.234 \multimap$ Irlanda

$21.130 \rightarrow$ Israel

$14.028 \rightarrow$ Japão

$14.305 \multimap$ Áustria

16.574

-Dinamarca

- Coreia do Sul

—-República Tcheca

9.240

- Noruega

Alguns países além do surto da doença vem enfrentando problemas financeiros, caso de Israel, que afora do aumento de casos, apresenta protestos em massa (BBC, 2020e). A Dinamarca foi um dos primeiros países europeus a reabrir parcialmente para a sociedade, sua abordagem para lidar com a pandemia poderia ser resumida com o slogan "Aja rápido e aja com força". No entanto, a rápida resposta do governo e a manipulação da crise não é o único elemento que explica o sucesso de lidar com a pandemia (OLAGNIER; MOGENSEN, 2020). Já a Suíça, assiste um aumento gradual de novos casos e os responsáveis científicos defendem que o fim da quarentena é precipitado, vale salientar que o país nunca a instaurou de forma generalizada (RFI, 2020b).

A Áustria conta com sistema de saúde de qualidade e um nível de autodisciplina de seus cidadãos que permitiram ao país nivelar a curva de contaminações e limitar o número de mortes relacionadas à COVID-19 (POINTS, 2020). A Irlanda freou a flexibilização do bloqueio devido ao aumento de casos, ainda deixando obrigatório o uso de máscara, restrições de no máximo 50 pessoas, restrição de viagens não essenciais e bares, discotecas, cassinos, entre outros, que permaneceram fechados. Por fim, dentre os países analisados, a República Tcheca, atualmente livre da quarentena, mas em isolamento social e com uso obrigatório de máscaras e restrições tais como, os cidadãos da UE que chegam a negócios, ou estudantes universitários terão permissão para entrar, mas os estrangeiros não podem acessar o país (BBC, 2020b).

Os países com os maiores números de casos da doença na amostra são Estados Unidos, Brasil, Reino Unido, Espanha, Itália, Alemanha, França, Canadá, Bélgica, Países Baixos e Suécia, conhecidos por serem aqueles com maiores picos da doença, que é o caso do Brasil e Estados Unidos e, desse grupo, apenas Alemanha e Bélgica são liderados por mulheres (Figura 3). 
Enfrentamento aos impactos da COVID-19:

governos liderados por mulheres apresentam melhor resposta em prevenção a pandemia?

Figura 3 - Países da amostra com maiores números de casos absolutos da COVID-19

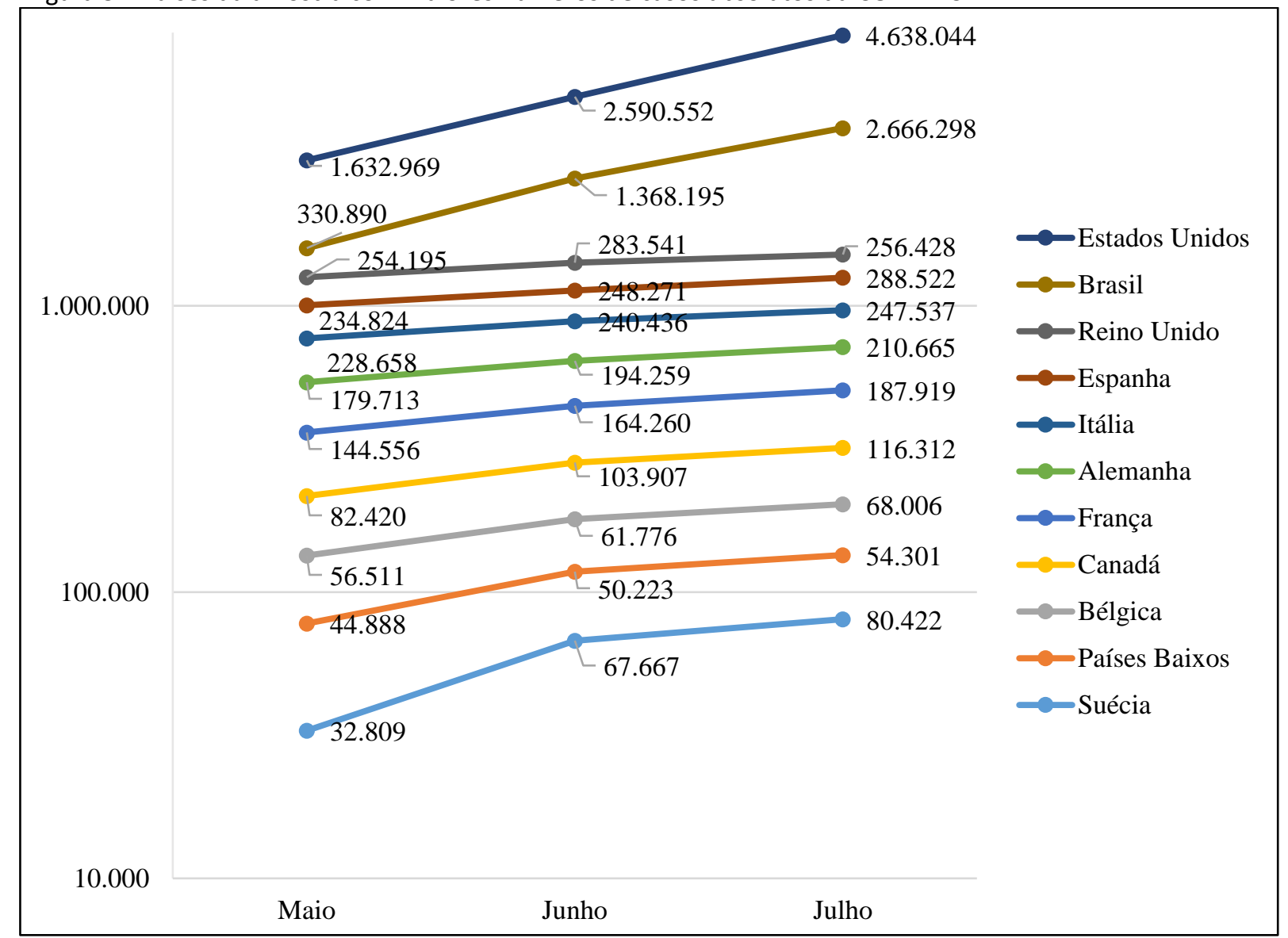

Fonte: elaborado pelos autores com base nos dados da pesquisa (2020).

A Alemanha tem se mostrado exemplo no combate à doença, infelizmente os altos números se dão a grande população e por estarem geograficamente próximo aos epicentros da Europa, como Itália, França e Inglaterra. Quanto às respostas à doença, uma significativa quantidade de exames foi realizada, além disso o sistema de saúde está absorvendo os pacientes que necessitam de tratamento hospitalar. Cabe destacar que os investimentos do governo federal também foram aliados positivos no combate a pandemia que anunciou 0 aumento da sua capacidade de leitos de UTI com ventiladores, de 28 mil para 50 mil (BONIS, 2020).

A Bélgica apresentou, no auge da pandemia, uma situação delicada pela superavaliação de casos da COVID-19, em que algumas mortes foram confirmadas e estão na contagem de casos, assim como número de pessoas infectadas. De acordo com os últimos dados oficiais do país, na Bélgica, das 7.703 mortes, 53\% ocorreram em lares de idosos e cerca de $16 \%$ destas foram testadas positivas. O restante dos casos é apenas suspeição, mas aparecem como confirmados nas estatísticas (GAVIN LEE, 2020).

A Suécia, diferentemente dos seus vizinhos nórdicos, não utilizou medidas restritas de isolamento e foi criticada. A governante Annika Linde fez seu trabalho entre 2005 e 2013, afirmou recentemente que acreditava que restrições mais duras no início da pandemia poderiam ter salvado vidas (SAVAGE, 2020). França, Itália e Espanha foram epicentros da doença na Europa e hoje apresentam significativas quedas no número de mortes e de contágio, fazendo com que estes países relaxassem seus bloqueios e retomassem gradativamente suas atividades (BBC, 2020c). 
A estratégia do Reino Unido baseava-se na "mitigação" da pandemia e na "imunização de rebanho" ou infecção de grande parte da população, que na teoria desenvolveria a imunidade coletiva com o objetivo de proteger todos os cidadãos, o que foi comprovado não surtir efeitos positivos, causando muitas mortes no país pela exposição ao vírus. Atualmente, o país mudou sua tática de prevenção e vem diminuindo o número de casos (BBC, 2020d).

Brasil e Estados Unidos apresentaram os piores resultados até agora, liderando como países com maiores números de casos e mortes no mundo. Segundo, o Global Times (2020), as "táticas anticientíficas e negacionistas" desses países não apenas arrastam os dois países para um "abismo", mas também prejudicam o futuro do desenvolvimento social e econômico global.

O Canadá, vizinho de fronteira dos Estados Unidos, apresentou um quadro menos grave, com bloqueios de viagens a países com alto risco de infecção, compras de equipamentos de segurança de trabalhadores da saúde, comunicação com os habitantes e alívio econômico de impostos e obrigações (FARR, 2020).

\subsection{NÚMEROS DE CASOS A CADA 1.000.000 DE HABITANTES}

A avaliação de boas táticas de prevenção ou o quão bem/mal está um país no enfrentamento contra a COVID-19 é necessária para computar os números a cada 1.000 .000 de habitantes e não só, os valores absolutos, visto que cada país tem um número de habitantes distinto e com discrepâncias significativas.

Para efeitos de comparação de tempo ou espaço, é importante que se traga os dados para uma mesma realidade, por exemplo, seria errôneo verificar apenas as mortes em números absolutos de cada país e não levar em conta o tamanho da população e/ou território (ORGANIZAÇÃO PAN-AMERICANA DE SAÚDE, 2020).

Ao se observar os países com menores números de infectados em números absolutos e por milhão de habitantes, não se detectou diferenças expressivas (Figura 4) e, dos $10 \mathrm{com}$ menos casos a cada 1 milhão de habitantes, 4 deles são liderados por mulheres: Estônia, Grécia, Nova Zelândia e Hong Kong. Esses países apresentaram baixas taxas de contágio da população, não alcançando $0,2 \%$. Com a taxa de $0,01 \%$ de contágio observou-se Japão e Hong Kong, Nova Zelândia e Coreia do Sul apresentaram 0,02\%, Grécia e Austrália com 0,03\% e, por fim, Eslovênia e República Tcheca com 0,07\% e 0,08\%, respectivamente (Figura 4).

Finlândia e Estônia apresentaram 0,12\% e 0,14\%, respectivamente e vale salientar, que desses 10 países com menor contágio, 4 deles são liderados por mulheres: Hong Kong, Nova Zelândia, Grécia e Estônia.

Quanto aos países com números intermediários de casos por milhão; Dinamarca, Noruega e Alemanha são liderados por mulheres. Vale salientar que em julho, os números da Noruega estavam menores que da Estônia, Finlândia e República Tcheca que são países com menores números de casos por 1.000 .000 de habitantes. Dentre esses países listados, a taxa de contágio da população é de $0,17 \%$ na Noruega e, em torno de 0,25\% em Liechtenstein, Áustria, Dinamarca e Alemanha, entre 0,30\% na França, Canadá e Países Baixos e, 0,82\% e $1,25 \%$ em Israel e no Brasil, respectivamente. 
Enfrentamento aos impactos da COVID-19:

governos liderados por mulheres apresentam melhor resposta em prevenção a pandemia?

Figura 4 - Países com menor número de casos por milhão de COVID-19

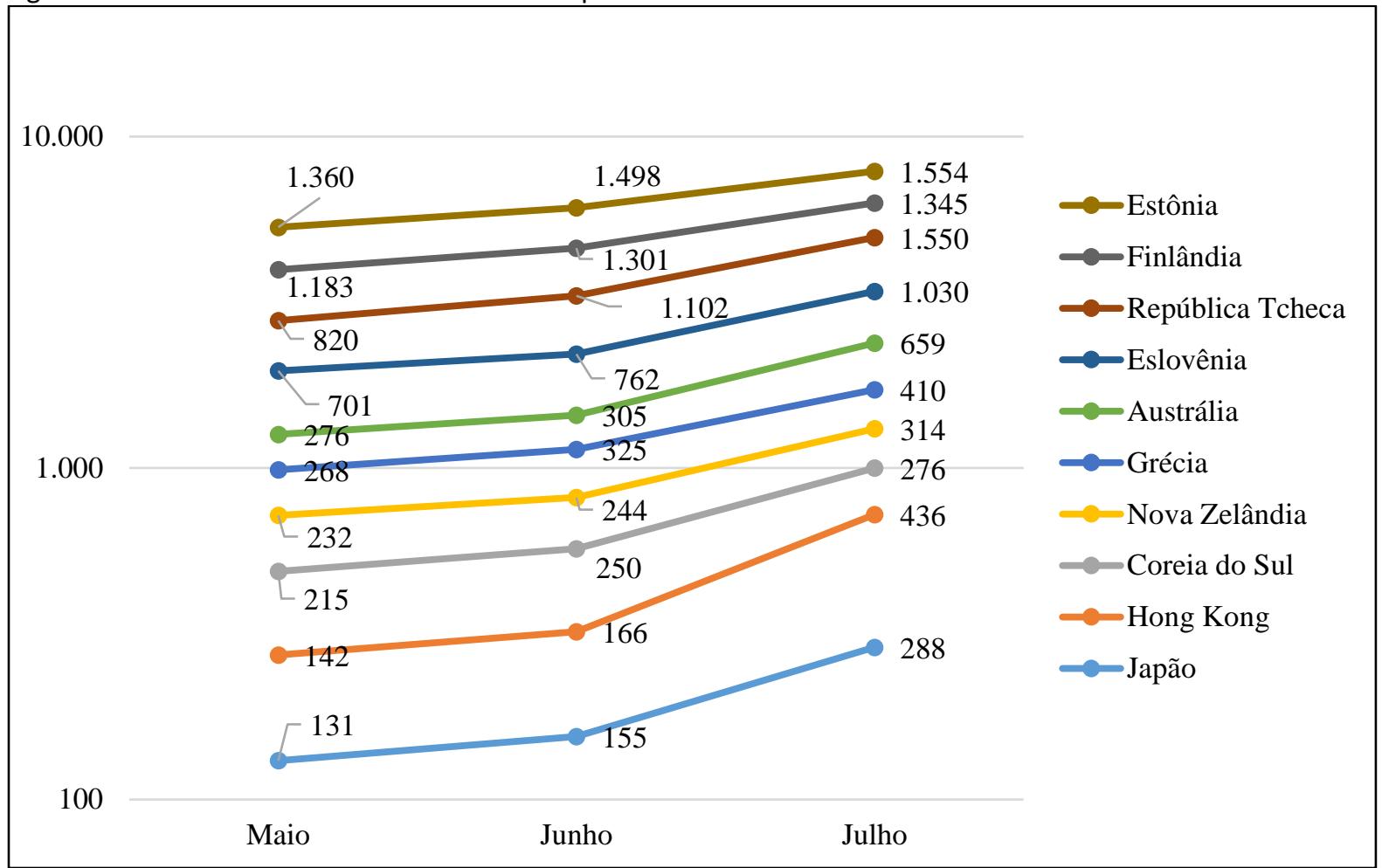

Fonte: elaborado pelos autores com base nos dados da pesquisa (2020).

Nos países com número intermediário de casos a cada milhão de habitantes, percebese que o Brasil está apresentando números semelhantes aos dos países da Figura 5, nos meses de maio e junho, porém em julho ultrapassa os outros países da amostra, ficando atrás somente dos Estados Unidos em número de infectados por milhão (Figura 5).

Figura 5 - Países com número intermediário de casos por milhão de COVID-19

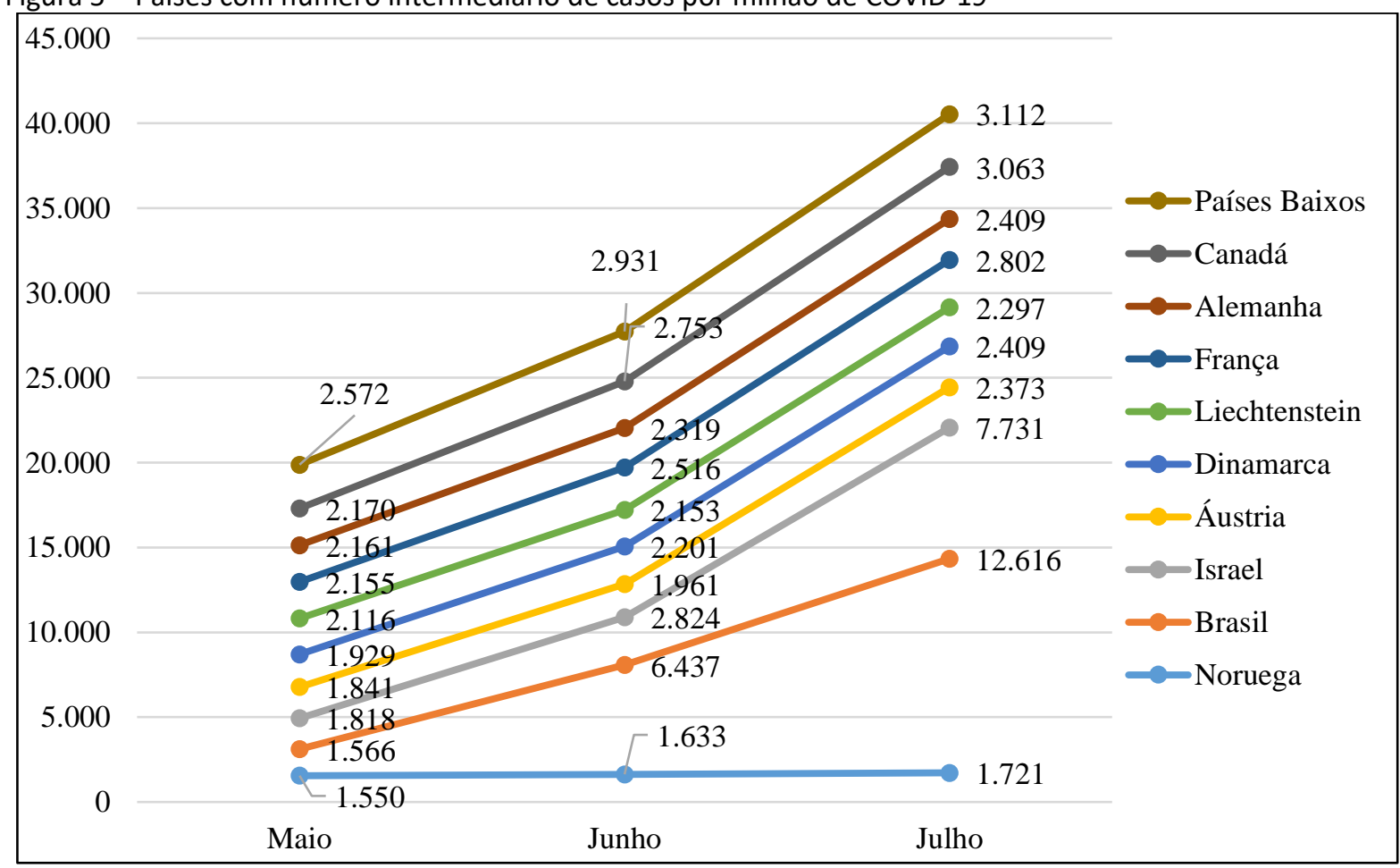

Fonte: elaborado pelos autores com base nos dados da pesquisa (2020). 
Dentre os países com maior número de casos por milhão estão Luxemburgo, Singapura, Espanha, Irlanda, Estados Unidos, Islândia, Bélgica, Reino Unido, Itália e Suíça. Dentre esses países, são governados por mulheres a Bélgica, Singapura e a Islândia e, no caso da Bélgica, conforme mencionado, há indícios que os números disponibilizados estão superavaliados, conforme Gavin Lee (2020) (Figura 6).

Figura 6 - Países com maiores números de casos por milhão de COVID-19

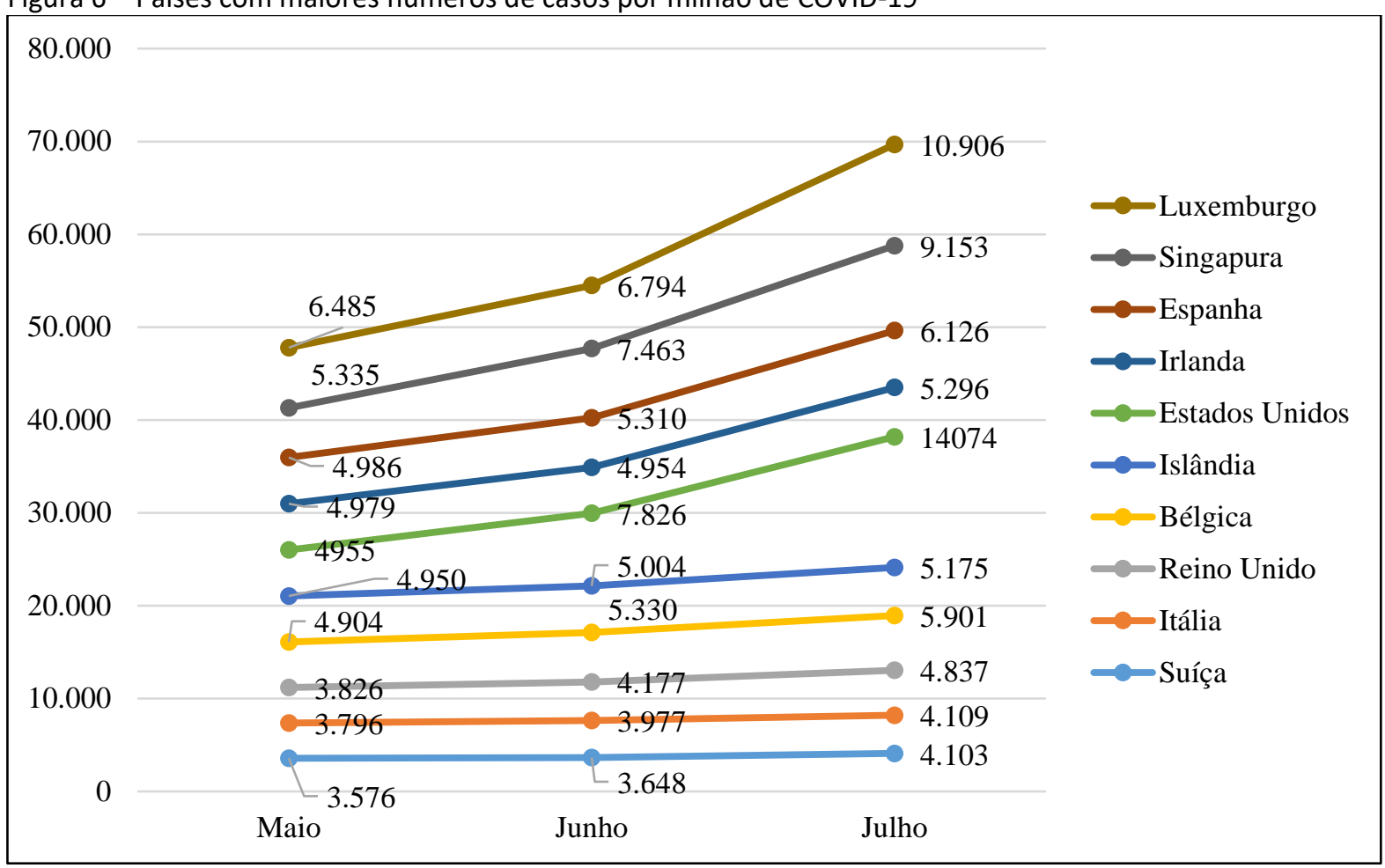

Fonte: elaborado pelos autores com base nos dados da pesquisa (2020).

Quanto a porcentagem de habitantes contaminados, esse grupo fica em torno de 0,50\% da população e os países Singapura, Luxemburgo e Estados Unidos tem 0,89\%, 1,07\% e $1,40 \%$, respectivamente.

\subsection{NÚMERO DE MORTES PELA COVID-19}

Dentre os países com menor número de mortes por COVID-19, se destaca Liechtenstein com apenas uma morte. Novamente se observa que países liderados por mulheres são a maioria, onde foram registrados menor número de casos, dentre estes, são 6: Grécia, Estônia, Singapura, Nova Zelândia, Islândia e Hong Kong (Figura 7). Esses países chegaram a 203 mortes até o fim de julho, como a Grécia, porém a maioria deles não chegou a alcançar 200 vítimas.

Variáveis como localização geográfica, número de habitantes e sistema de saúde desses países são fatores que contribuem para redução das mortes. Mas não há dúvidas que estes governantes obtiveram êxito em suas medidas de proteção contra o vírus e, já podem colher frutos de uma sociedade reaberta e com menores riscos de crises financeiras. 
Enfrentamento aos impactos da COVID-19:

governos liderados por mulheres apresentam melhor resposta em prevenção a pandemia?

Figura 7 - Países com menos mortes pela COVID-19

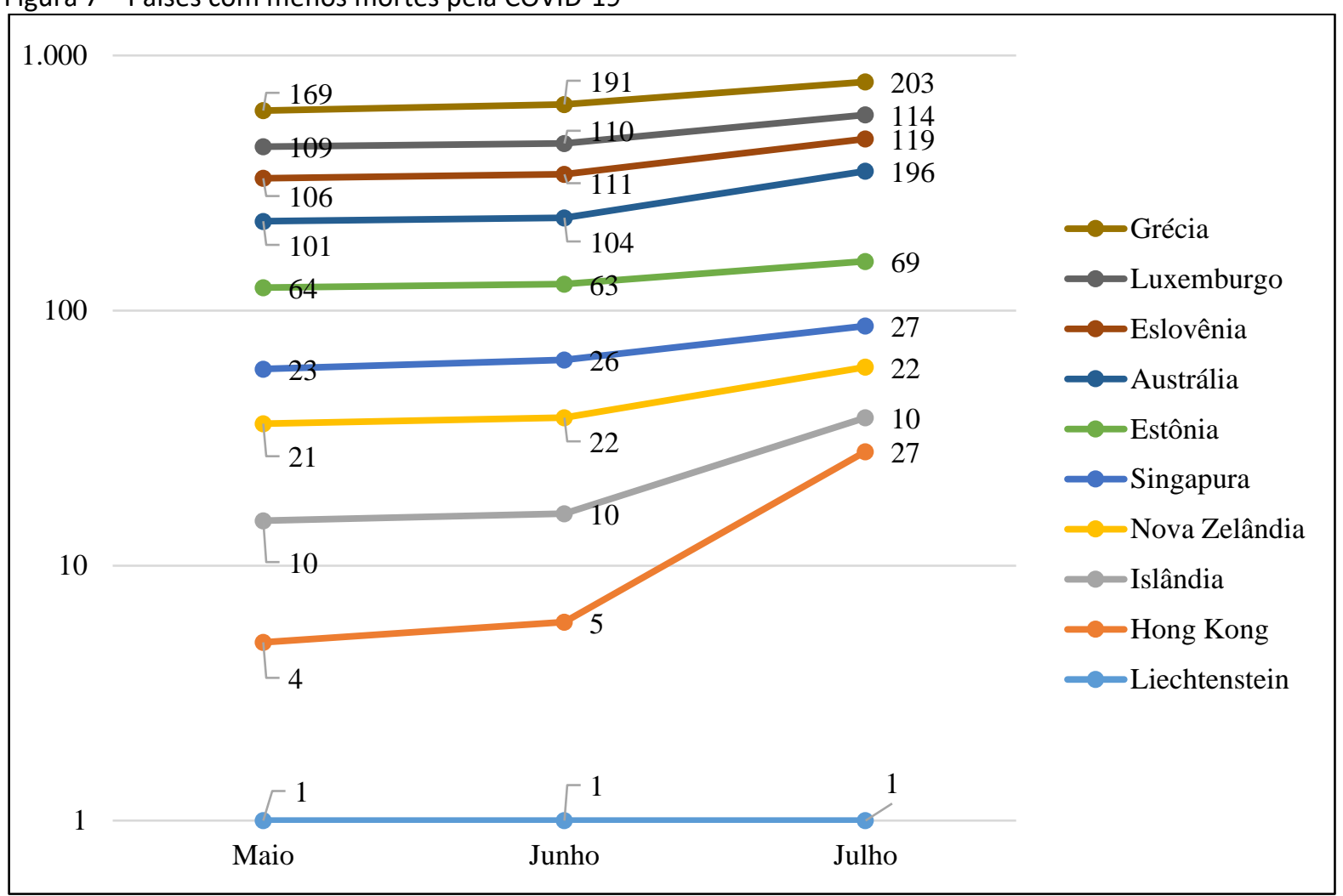

Fonte: elaborado pelos autores com base nos dados da pesquisa (2020).

Singapura apresentou a menor taxa de letalidade da amostra, com 0,05\% dos casos que se tornam vítimas da doença. Islândia, Israel e Hong Kong também apresentam números baixos, em torno de $0,80 \%$ (Figura 8 ).

Figura 8 - Países com número intermediário de mortes por COVID-19

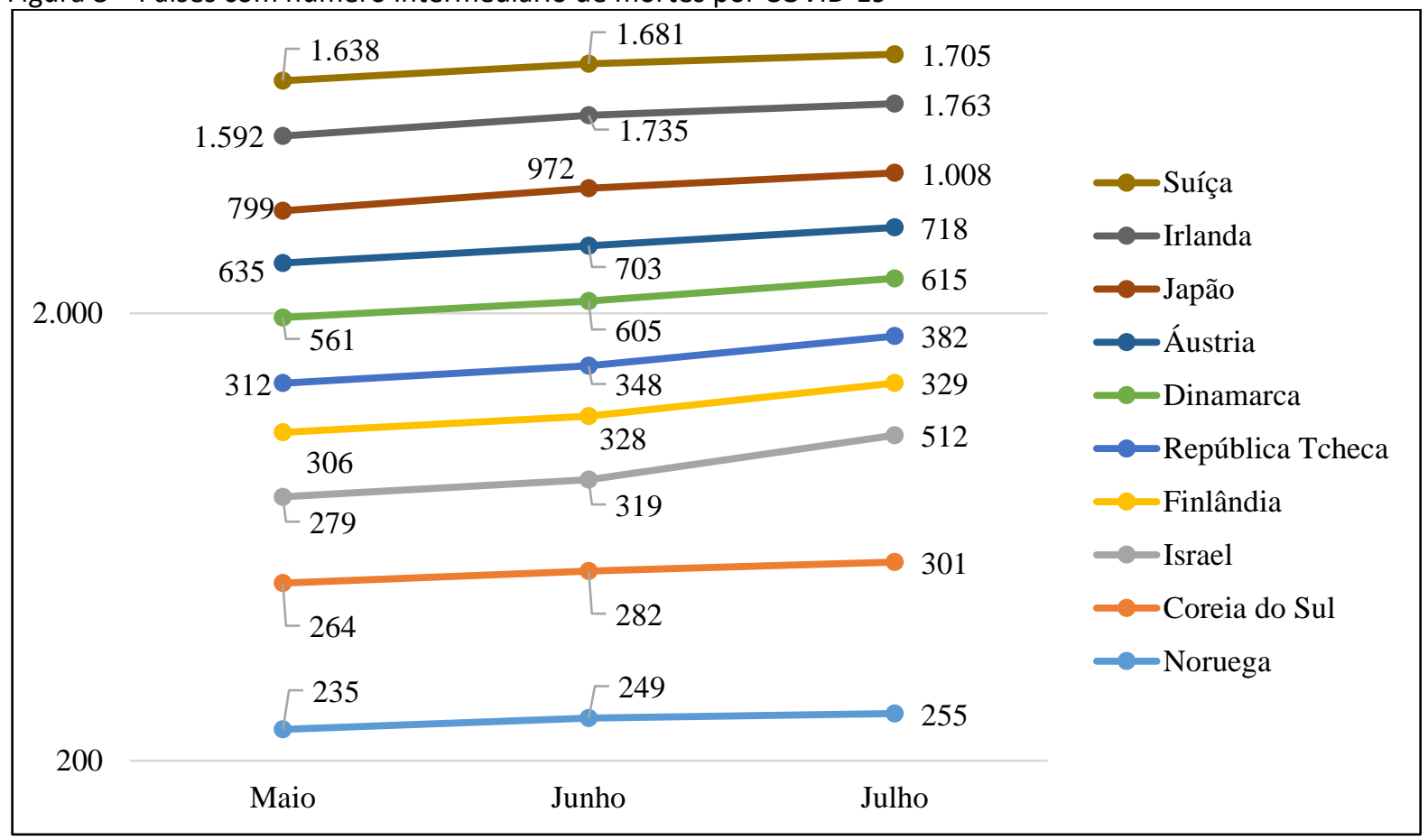

Fonte: elaborado pelos autores com base nos dados da pesquisa (2020). 
Os países com número praticamente estável de mortes são: Noruega, Coreia do Sul, Finlândia, República Tcheca, Suíça, Israel, Áustria, Dinamarca, Japão e Irlanda, 3 deles governados por mulheres: Noruega, Finlândia e Dinamarca. O percentual de letalidade desses países é em torno de $5 \%$, com a Irlanda ultrapassando um pouco, com 6,5\% de letalidade dos casos reportados e a Coreia com 2,38\% com vítimas (Figura 9).

Figura 9 - Países com maior número de mortes por COVID-19

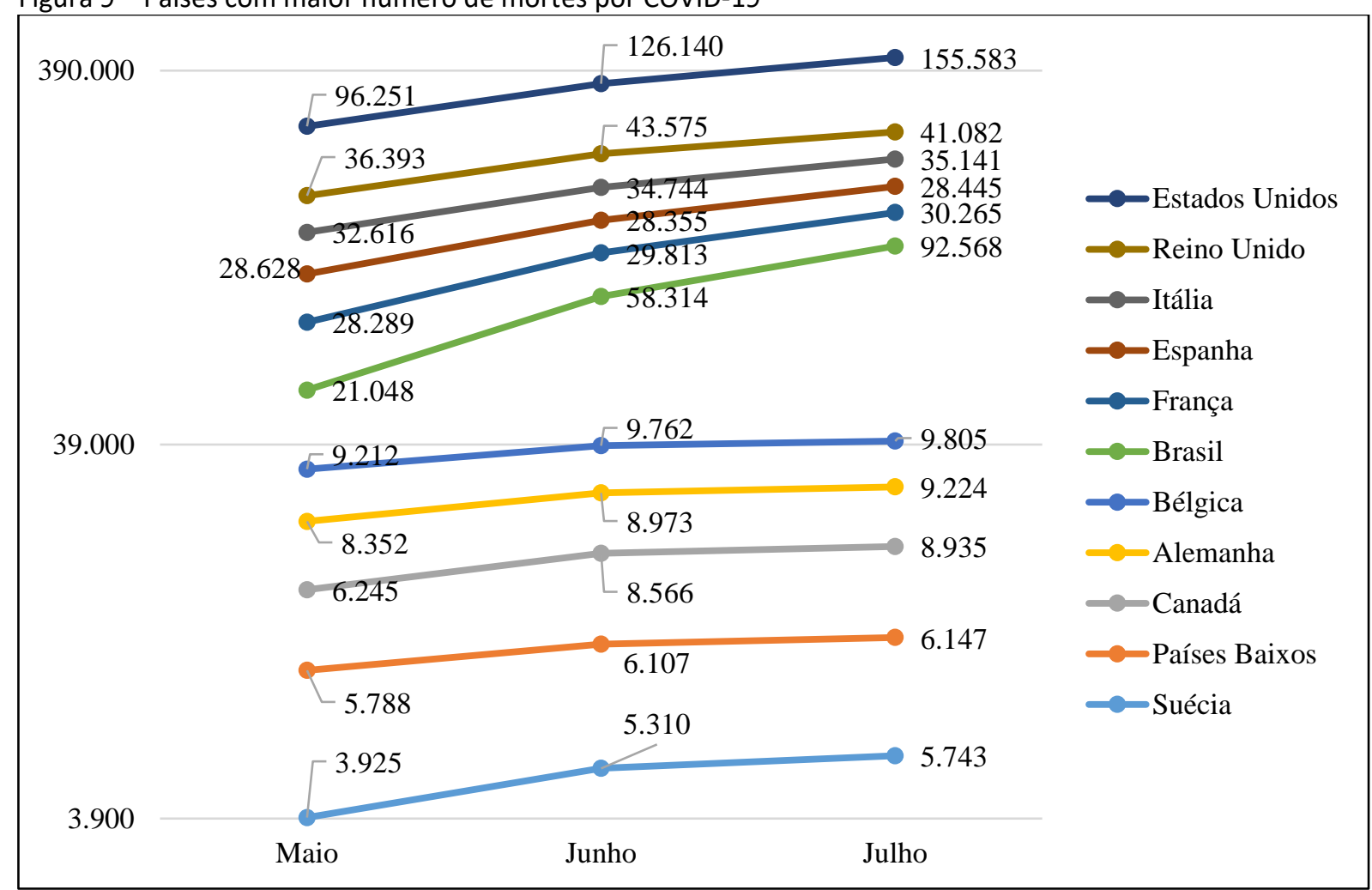

Fonte: elaborado pelos autores com base nos dados da pesquisa (2020).

Por fim, os países com maiores números de vítimas pela COVID-19 são: Estados Unidos, Reino Unido, Itália, Espanha, França, Brasil, Bélgica, Alemanha, Canadá, Países Baixos e Suécia, muitos reconhecidamente epicentros da doença. Dentre estes países, apenas Alemanha e Bélgica são governadas por mulheres.

As taxas de letalidade desses países podem chegar a mais de $19 \%$ como foi o caso da França no mês de julho, apesar de serem países com o maior número de mortes e contágios. O Brasil e os Estados Unidos exibiram taxas de letalidade em torno de 6\%, enquanto os outros países apresentaram aproximadamente 10\% de letalidade no mês de julho de 2020.

\subsection{SEGUNDA ONDA DE COVID-19}

Uma segunda onda de COVID-19 se perpetuou sobre alguns países, entre eles os selecionados na amostra da presente pesquisa, trazendo novas medidas de prevenção e, em alguns casos, da economia também (Quadro 2).

Alguns países ainda têm a ideia de apenas uma "probabilidade de segunda onda", outros já se preparam para o pior. No Brasil, por exemplo, medidas ainda não foram tomadas, mas já se notícia que o vírus está menos letal e atingindo dessa vez, a população mais jovem. 
Enfrentamento aos impactos da COVID-19:

governos liderados por mulheres apresentam melhor resposta em prevenção a pandemia?

Quadro 2 - Medidas adotadas para o enfrentamento da segunda onda de COVID-19

\begin{tabular}{|c|c|c|}
\hline Países & Medidas & Fonte \\
\hline Alemanha & $\begin{array}{l}\text { Os chefes dos } 16 \text { estados federais da Alemanha concordaram sobre novas } \\
\text { restrições uniformes para conter surtos de focos de COVID-19. Em cidades } \\
\text { e regiões com mais de } 35 \text { infecções por } 100.000 \text { pessoas no espaço de } 75 \\
\text { dias, as máscaras serão obrigatórias em locais públicos e/ou reuniões. No } \\
\text { caso da taxa de infecção de sete dias sobe para mais de } 50 \text { casos por } \\
100.000 \text { pessoas, as reuniões privadas serão limitadas ao máximo de } 10 \\
\text { participantes ou membros de duas famílias, e bares e restaurantes tem } \\
\text { ordem de fechamento às } 23 \mathrm{~h} \text {. }\end{array}$ & $\begin{array}{c}\text { The Guardian } \\
\text { (2020) }\end{array}$ \\
\hline Austrália & $\begin{array}{l}\text { Um surto crescente em Melbourne, a segunda maior cidade da Austrália, } \\
\text { forçou o estado de Victoria de volta ao bloqueio, com a maioria dos } \\
\text { moradores obrigados a ficar em casa. Em julho, a Austrália atingiu o } \\
\text { segundo maior aumento diário em casos, } 438 \text {. }\end{array}$ & $\begin{array}{l}\text { Time } \\
(2020)\end{array}$ \\
\hline Áustria & $\begin{array}{l}\text { A Áustria reintroduziu o uso obrigatório de máscaras em lojas e transporte } \\
\text { público, impôs horário de fechamento à } 1 \mathrm{~h} \text { em bares e restaurantes e } \\
\text { limitou as reuniões sem assento em locais públicos a } 10 \text { pessoas. Um "mini } \\
\text { lockdown" aconteceu na região de Kuchl, no estado de Land Salzburg, onde } \\
\text { eventos públicos estão proibidos, assim como visitas a lares de idosos e } \\
\text { restaurantes fecham às } 17 \mathrm{~h} \text {. }\end{array}$ & $\begin{array}{c}\text { The Guardian } \\
\text { (2020) }\end{array}$ \\
\hline Bélgica & $\begin{array}{l}\text { As lojas fecham às } 22 \mathrm{~h} \text {, os cafés às } 23 \mathrm{~h} \text { e os restaurantes à } 1 \mathrm{~h} \text { com máximo } \\
\text { de } 10 \text { pessoas à mesa em restaurantes e quatro pessoas em cafés. Não mais } \\
\text { do que quatro pessoas (exceto menores de } 12 \text { anos e aqueles que vivem } \\
\text { sob o mesmo teto) podem se reunir em casa ou em espaços públicos. Cada } \\
\text { pessoa deve limitar o contato com outras por mais de } 15 \text { minutos a um } \\
\text { máximo de três por mês. Para eventos públicos, não mais que } 200 \text { pessoas } \\
\text { em áreas internas e } 400 \text {, nas externas. Festivais, discotecas estão proibidos } \\
\text { e todos os outros eventos esportivos e culturais somente em espaços } \\
\text { abertos e são orientados a trabalhar em casa sempre que possível. }\end{array}$ & $\begin{array}{c}\text { The Guardian } \\
\text { (2020) }\end{array}$ \\
\hline Brasil & Não há novas medidas. & - \\
\hline Canadá & $\begin{array}{l}\text { Ontário introduziu medidas de saúde pública mais rígidas no início de } \\
\text { novembro, incluindo pausar círculos sociais e obrigar o uso de máscara em } \\
\text { toda a província, onde o distanciamento físico não é possível. Quebec } \\
\text { também revelou novas ferramentas legais para a polícia aplicar medidas de } \\
\text { saúde pública mais rígidas que entram em vigor nas zonas vermelhas. }\end{array}$ & $\begin{array}{l}\text { Miller } \\
(2020)\end{array}$ \\
\hline Coreia do Sul & $\begin{array}{l}\text { O governo sul-coreano respondeu ao surto aumentando a capacidade de } \\
\text { teste e rastreando e isolando agressivamente os casos em potencial. O país } \\
\text { introduziu algumas medidas de distanciamento social, que restringem } \\
\text { reuniões e fecham escolas e locais de trabalho. }\end{array}$ & $\begin{array}{c}\text { Lee } \\
(2020)\end{array}$ \\
\hline Dinamarca & $\begin{array}{l}\text { Novas restrições foram impostas em } 19 \text { de setembro e estendidas até } 31 \text { de } \\
\text { outubro onde máscaras são obrigatórias no transporte público e em cafés e } \\
\text { restaurantes que devem fechar até } 22 \mathrm{~h} \text { e as reuniões públicas limitadas a } \\
50 \text { participantes. Em abril, a Dinamarca se tornou um dos primeiros países } \\
\text { ocidentais a reabrir escolas, com ensino ministrado em "microgrupos" de } \\
\text { não mais de } 12 \text { e horários escalonados, sem o uso obrigatório de máscara. }\end{array}$ & $\begin{array}{c}\text { The Guardian } \\
\text { (2020) }\end{array}$ \\
\hline Eslovênia & Não há novas medidas. & - \\
\hline Espanha & $\begin{array}{l}\text { Quatro meses após estritas } 13 \text { semanas de bloqueio, a Espanha se tornou o } \\
\text { país mais afetado da Europa ocidental e, Madrid, a área mais atingida. } \\
\text { Máscaras são obrigatórias em todos os espaços externos em todo o país. } \\
\text { Madrid e oito cidades satélites estão em bloqueio limitado, com pessoas } \\
\text { autorizadas a entrar ou sair das áreas afetadas por motivos de trabalho, } \\
\text { escola, médicos ou motivos urgentes. Os encontros públicos e privados são } \\
\text { limitados a seis pessoas, e os bares e restaurantes devem funcionar com } \\
50 \% \text { de sua capacidade interna e fechar até às } 23 \mathrm{~h} \text {. A partir de } 15 \text { de } \\
\text { outubro, bares e restaurantes na Catalunha limitar-se-á a oferecer serviços } \\
\text { de entrega ou take-away. Lojas e mercados funcionarão com } 30 \% \text { da }\end{array}$ & $\begin{array}{c}\text { The Guardian } \\
\text { (2020) }\end{array}$ \\
\hline
\end{tabular}


Sarah Amaral Fabrício, Denize Demarche Minatti Ferreira e José Alonso Borba

\begin{tabular}{|c|c|c|}
\hline & $\begin{array}{l}\text { capacidade e academias, cinemas e teatros com } 50 \% \text { e parques infantis } \\
\text { fecharão às } 20 \mathrm{~h} \text {. O governo de Navarra ordenou que bares e restaurantes } \\
\text { reduzissem a capacidade para } 30 \% \text { e fechassem às } 22 \mathrm{~h} \text {. }\end{array}$ & \\
\hline EUA & Não há novas medidas. & - \\
\hline Estônia & Não há novas medidas. & - \\
\hline Finlândia & $\begin{array}{l}\text { A Finlândia lançou novas medidas em outubro, onde máscaras são exigidas } \\
\text { no transporte público, nos aeroportos e no parlamento, e recomendadas } \\
\text { para funcionários em lojas. Os clientes em bares e restaurantes devem estar } \\
\text { sentados e nas seis regiões mais afetadas, os estabelecimentos devem } \\
\text { operar com metade da capacidade e fechar às } 23 \mathrm{~h} \text {. Em áreas menos } \\
\text { afetadas, bebidas alcoólicas podem ser servidas até meia-noite e os locais } \\
\text { devem fechar à } 1 \mathrm{~h} \text {, sem restrições ao número de clientes. O máximo para } \\
\text { reuniões públicas internas e externas foi reduzido de } 500 \text { pessoas para } 50 \\
\text { em setembro. Escolas estão abertas normalmente, sem máscaras, mas com } \\
\text { aulas online quando um surto é detectado e funcionários aconselhados a } \\
\text { trabalhar de casa, em áreas onde o número de casos está aumentando. }\end{array}$ & $\begin{array}{c}\text { The Guardian } \\
\text { (2020) }\end{array}$ \\
\hline França & $\begin{array}{l}\text { As máscaras são obrigatórias ao ar livre e espaços internos em áreas onde } \\
\text { o vírus se espalha rapidamente. O toque de recolher entra em vigor na } \\
\text { região de Paris e em oito outras cidades consideradas em "alerta máximo" } \\
\text { a partir da meia-noite. O toque de recolher das } 21 \mathrm{~h} \text { às } 6 \mathrm{~h} \text { será imposto por } \\
\text { pelo menos quatro semanas, podendo ser prorrogado até } 1 \text { o de dezembro. } \\
\text { Os bares já estão fechados nas áreas de "alerta máximo", enquanto os } \\
\text { restaurantes permanecem abertos, até às } 21 \mathrm{~h} \text {. Os clientes devem deixar } \\
\text { contato e não pode haver mais de seis pessoas na mesa. Eventos com mais } \\
\text { de } 1.000 \text { pessoas são proibidos em áreas de alto risco, bem como reuniões } \\
\text { com mais de } 10 \text { pessoas em locais públicos, parques e jardins. Um máximo } \\
\text { de seis pessoas são aconselhadas em reuniões privadas em casa. As salas de } \\
\text { aula, cantinas e as universidades devem funcionar com } 50 \% \text { da capacidade; } \\
\text { trabalhar em casa, sempre que possível, de } 2 \text { a } 3 \text { dias por semana. }\end{array}$ & $\begin{array}{c}\text { The Guardian } \\
\text { (2020) }\end{array}$ \\
\hline Grécia & $\begin{array}{l}\text { As máscaras são obrigatórias em locais fechados, incluindo espaços de } \\
\text { trabalho, escolas e todo transporte público, e incentivadas em restaurantes } \\
\text { quando os clientes não estão comendo ou bebendo, obrigatórias em } \\
\text { reuniões de grupo. Restaurantes, bares e cafés devem fechar à meia-noite } \\
\text { e não mais do que quatro pessoas podem ser servidas à mesa, a menos que } \\
\text { sejam parentes, quando o número for de seis. As reuniões internas e } \\
\text { externas são limitadas a nove, e não mais do que } 20 \text { podem comparecer a } \\
\text { batismos, casamentos ou funerais. Concertos são proibidos e escolas estão } \\
\text { operando, embora alguns tenham fechado por causa de surtos. As horas de } \\
\text { trabalho são escalonadas no setor civil, e pelo menos } 40 \% \text { da força de } \\
\text { trabalho nos setores público e privado são obrigados a trabalhar em casa. }\end{array}$ & $\begin{array}{c}\text { The Guardian } \\
\text { (2020) }\end{array}$ \\
\hline Hong Kong & $\begin{array}{l}\text { O governo tomou medidas para conter a segunda onda proibindo a entrada } \\
\text { de não residentes, impediram viajantes de transitar pelo aeroporto e } \\
\text { implementaram quarentena estrita e testes em todas as chegadas, } \\
\text { independentemente da origem. Aqueles em quarentena domiciliar } \\
\text { receberam pulseiras eletrônicas para rastreamento. o governo } \\
\text { implementou restrições para venda de álcool em bares e fechou academias } \\
\text { e instalações esportivas. Muitos restaurantes e cafés fecharam e os que } \\
\text { permaneceram abertos reduziram a capacidade para aumentar a distância } \\
\text { entre clientes ou colocar barreiras físicas entre as mesas. }\end{array}$ & $\begin{array}{l}\text { Yeung } \\
(2020)\end{array}$ \\
\hline Irlanda & $\begin{array}{l}\text { As máscaras permanecem obrigatórias nos transportes públicos e em lojas, } \\
\text { teatros, salões de beleza e alguns outros ambientes internos e proibição de } \\
\text { visitas a casas ou jardins foi imposta, com exceções para quem cuida de } \\
\text { crianças ou pessoas vulneráveis. Em ambientes externos ou jardins de até } \\
\text { seis pessoas e no máximo duas famílias podem se reunir, mantendo } \\
\text { distância social. Bares e restaurantes podem funcionar como take-away ou } \\
\text { servir comida ao ar livre. Cavan, Donegal e Monaghan, condados que fazem } \\
\text { fronteira com a Irlanda do Norte, um hotspot de vírus, têm restrições }\end{array}$ & $\begin{array}{c}\text { The Guardian } \\
\text { (2020). }\end{array}$ \\
\hline
\end{tabular}


Enfrentamento aos impactos da COVID-19:

governos liderados por mulheres apresentam melhor resposta em prevenção a pandemia?

\begin{tabular}{|c|c|c|}
\hline & $\begin{array}{l}\text { adicionais, incluindo o fechamento de negócios não essenciais, como } \\
\text { academias, piscinas e centros de lazer. }\end{array}$ & \\
\hline Islândia & Não há novas medidas. & - \\
\hline Israel & Não há novas medidas. & - \\
\hline Itália & $\begin{array}{l}\text { As máscaras são obrigatórias em espaços fechados, como lojas, bares, } \\
\text { museus, aeroportos e no transporte público. Bares e restaurantes devem } \\
\text { fechar à meia-noite e as mesas devem ser higienizadas após cada cliente e } \\
\text { estar a pelo menos } 1 \text { metro de distância. As pessoas são aconselhadas a } \\
\text { organizar reuniões de no máximo seis dentro de casas e usar máscaras } \\
\text { quando não se mantém distância segura. As escolas reabriram em } \\
\text { setembro, onde professores e alunos com mais de seis anos devem usar } \\
\text { máscaras, exceto se estiverem sentados em carteiras com distanciamento } \\
\text { físico mantido e com temperaturas medidas na chegada. }\end{array}$ & $\begin{array}{l}\text { The Guardian } \\
\text { (2020) }\end{array}$ \\
\hline Japão & $\begin{array}{l}\text { A ilha de Hokkaido, ao norte, foi a primeira no Japão a declarar emergência } \\
\text { no final de fevereiro, pois apresentava maior número de infecções pela } \\
\text { COVID-19. Sob o estado de emergência, escolas foram fechadas, reuniões } \\
\text { canceladas e as pessoas aconselhadas a ficar em casa. }\end{array}$ & $\begin{array}{c}\text { Lee } \\
(2020)\end{array}$ \\
\hline Liechtenstein & Não há novas medidas. & - \\
\hline Luxemburgo & $\begin{array}{l}\text { Uma segunda onda de infecções pela COVID-19 parece provável e à medida } \\
\text { que o impacto econômico incapacitante das medidas de bloqueio começa a } \\
\text { surgir, um segundo bloqueio parece improvável. }\end{array}$ & $\begin{array}{l}\text { Delano } \\
(2020)\end{array}$ \\
\hline Noruega & $\begin{array}{l}\text { As restrições foram abrandadas, permitindo que bebidas alcoólicas sejam } \\
\text { servidas após a meia-noite e até } 600 \text { pessoas participem em eventos ao ar } \\
\text { livre, mas os municípios impuseram medidas locais que variam de acordo } \\
\text { com as taxas de infecção. Na região de Oslo, as máscaras são obrigatórias } \\
\text { no transporte público quando a distância de } 1 \text { metro não pode ser } \\
\text { respeitada, bem como para todos os cuidadores domiciliares. Restaurantes, } \\
\text { cafés e outros locais onde são servidos alimentos e/ou bebidas alcoólicas } \\
\text { devem registrar seus clientes. Os eventos indoor com mais de } 50 \\
\text { participantes sem assentos fixos são proibidos em alguns municípios, assim } \\
\text { como reuniões privadas com mais de } 20 \text { participantes ou onde a distância } \\
\text { de } 1 \text { metro não pode ser mantida. As escolas reabriram em abril e os alunos } \\
\text { não têm se mostrado fator significativo de novas infecções e a maioria dos } \\
\text { municípios recomenda trabalhar em casa. }\end{array}$ & $\begin{array}{l}\text { The Guardian } \\
\text { (2020) }\end{array}$ \\
\hline $\begin{array}{l}\text { Nova } \\
\text { Zelândia }\end{array}$ & $\begin{array}{l}\text { A resposta da COVID-19 da Nova Zelândia é considerada a melhor do } \\
\text { mundo, segundo especialistas empresariais globais, o país agiu de forma } \\
\text { rápida e eficaz nas duas ondas, tendo poucos infectados e poucas mortes. }\end{array}$ & $\begin{array}{l}\text { Farrer } \\
(2020)\end{array}$ \\
\hline Países Baixos & $\begin{array}{l}\text { As máscaras são obrigatórias no transporte público e possivelmente } \\
\text { obrigatórias em todos os espaços públicos fechados. Enquanto isso, as } \\
\text { pessoas são "fortemente aconselhadas" a usá-las em lojas, museus, } \\
\text { escritórios do governo, cinemas e teatros e os cafés, bares e restaurantes e } \\
\text { cafeterias que serve cannabis estão fechados por pelo menos quatro } \\
\text { semanas, exceto para viagem. A venda e porte de álcool estão proibidos } \\
\text { entre às } 20 \mathrm{~h} \text { e 7h. As lojas que não forem de alimentos também devem } \\
\text { fechar às } 20 \mathrm{~h} \text { e todos os eventos para mais de } 30 \text { pessoas foram cancelados } \\
\text { e não mais de três visitantes podem ser recebidos em casa, exceto crianças. } \\
\text { Encontros em locais públicos não devem exceder quatro pessoas que não } \\
\text { forem da mesma casa. As escolas permanecem abertas, mas podem fechar } \\
\text { se houver aumento das infecções e, as máscaras são recomendadas, pois } \\
\text { são nas universidades e faculdades, e devem se tornar obrigatórias assim } \\
\text { que a legislação for aprovada. }\end{array}$ & $\begin{array}{l}\text { The Guardian } \\
\text { (2020) }\end{array}$ \\
\hline Reino Unido & $\begin{array}{l}\text { As pessoas na Inglaterra terão o dever legal de se auto isolar por } 14 \text { dias se } \\
\text { o teste for positivo ou se forem instruídas a fazê-lo e rastreamento, com } \\
\text { multas de até } £ 10.000 \text {. Aqueles que recebem benefícios têm direito a } \\
\text { auxílio único de } £ 500 \text { se enfrentarem perda de rendimentos por } \\
\text { isolamento. A partir de outubro, cerca de } 13,5 \text { milhões de pessoas em todo }\end{array}$ & $\begin{array}{l}\text { Davies } \\
(2020)\end{array}$ \\
\hline
\end{tabular}


Sarah Amaral Fabrício, Denize Demarche Minatti Ferreira e José Alonso Borba

\begin{tabular}{|c|c|c|}
\hline & $\begin{array}{l}\text { o Reino Unido, incluindo partes do nordeste e noroeste terão os toques de } \\
\text { recolher às } 22 \mathrm{~h} \text { para bares e restaurantes, sendo que alguns destes só } \\
\text { poderão oferecer serviços de take-away. }\end{array}$ & \\
\hline $\begin{array}{l}\text { República } \\
\text { Tcheca }\end{array}$ & $\begin{array}{l}\text { O país tem o pior registro de infecção da Europa, depois de anunciar seu } \\
\text { sucesso na primavera como um dos primeiros países a introduzir o uso de } \\
\text { máscara. O estado de emergência foi introduzido em } 5 \text { de outubro, seguido } \\
\text { por uma série de restrições, as máscaras são obrigatórias em espaços } \\
\text { públicos internos, incluindo transporte público, bem como em pontos ao ar } \\
\text { livre, plataformas e salas de espera. Os pubs e restaurantes fecham a partir } \\
\text { de } 14 \text { de outubro e estão restritos à venda para levar, até as } 20 \mathrm{~h} \text {. Reuniões } \\
\text { de mais de seis pessoas são proibidas com apenas exceções especificadas. } \\
\text { Todas as escolas exceto jardins de infância mudaram para o ensino à } \\
\text { distância e os alunos da escola primária divididos em meias-classes. }\end{array}$ & $\begin{array}{l}\text { The Guardian } \\
\text { (2020) }\end{array}$ \\
\hline Singapura & $\begin{array}{l}\text { Apesar de cautelosos e em estado de alerta, Singapura ainda não realizou } \\
\text { novas prevenções para uma segunda onda. }\end{array}$ & $\begin{array}{l}\text { Khalik } \\
\text { (2020) }\end{array}$ \\
\hline Suécia & $\begin{array}{l}\text { As novas regras entraram em vigor em } 19 \text { de outubro, permitindo às } \\
\text { autoridades introduzir as suas próprias orientações o que pode incluir } \\
\text { recomendações para evitar transporte público, viagens, visitas a pessoas de } \\
\text { grupo de risco e idas a shopping, academias e piscinas. No país máscaras } \\
\text { não são recomendadas. As regras nacionais exigem que os clientes em bares } \\
\text { e restaurantes sejam separados por pelo menos } 1 \text { metro, e são proibidos } \\
\text { encontros a mais de 50. As pessoas são incentivadas a trabalhar em casa, a } \\
\text { ficar reclusas se apresentarem sintomas, a lavar as mãos, a respeitar o } \\
\text { distanciamento físico, evitar grandes reuniões sociais e usar outros meios } \\
\text { de transporte que não o transporte público, se possível. Pessoas em grupos } \\
\text { de alto risco ou com mais de } 70 \text { anos devem evitar lojas, restaurantes e } \\
\text { transportes públicos e, ter alimentos ou medicamentos entregues. }\end{array}$ & $\begin{array}{l}\text { The Guardian } \\
\text { (2020) }\end{array}$ \\
\hline Suíça & $\begin{array}{l}\text { Quatorze das } 26 \text { autoridades da Suíça estão exigindo que as pessoas } \\
\text { usem máscaras durante compras com horário limitado, também no } \\
\text { funcionamento de bares e restaurantes. O governo suíço relaxou as } \\
\text { restrições em } 1 \text { o de outubro para permitir eventos culturais e esportivos } \\
\text { com mais de } 1.000 \text { visitantes. }\end{array}$ & $\begin{array}{l}\text { The Guardian } \\
\text { (2020) }\end{array}$ \\
\hline
\end{tabular}

Fonte: elaborado pelos autores com base nos dados da pesquisa (2020).

Vale destacar a eficácia da prevenção da COVID-19 na Nova Zelândia, que se tornou o melhor país do mundo quanto às respostas contra a doença, segundo Farrer (2020) para aumentar as chances de reeleição de Jacinda Ardern, visto que o país obteve a melhor classificação em estabilidade, economia, controle de vírus e resiliência. $O$ índice criado por uma pesquisa do Bloomberg Media pontua a Nova Zelândia com 238, acima do segundo colocado Japão com 204 e Taiwan em terceiro com 198. A Austrália foi o sexto com 151, enquanto o Reino Unido e os EUA - apesar de seus altos números de casos e fatalidades da COVID-19 - foram o nono e o décimo.

\section{REFLEXÕES FINAIS}

O presente artigo comparou as práticas de prevenção à COVID-19 em países liderados por mulheres e por homens e verificou a partir dos fatos expostos, que há uma carência de mulheres como líderes mundiais. Na pesquisa realizada se detectou que dos 31 países apenas 10 são chefiados por mulheres (menos de $1 / 3$ da amostra). Ainda assim, se observa bons resultados na luta contra a COVID-19 entre esses países, especialmente: Nova Zelândia, Hong Kong, Grécia, Estônia e Islândia, mostraram ótimos resultados e baixos índices de contágio e letalidade.

Alemanha e Bélgica apresentaram resultados não tão significativos, mas ainda assim são exemplos de lideranças, a Alemanha pelo aumento da sua capacidade de leitos de UTI

RGO - Revista Gestão Organizacional, Chapecó, v. 14, n. 1, p. 390-415, jan./abr. 2021. 
Enfrentamento aos impactos da COVID-19:

governos liderados por mulheres apresentam melhor resposta em prevenção a pandemia?

com ventiladores, de 28 mil para 50 mil e, Bélgica por superavaliar os casos da COVID-19, talvez por prevenção e maior isolamento de idosos.

Hong Kong e Singapura também apresentaram boas práticas, principalmente por estarem mais bem preparadas para casos de pandemias, desastres naturais, entre outros. Esses países trabalham com respostas rápidas do governo e com a população bem informada sobre doenças respiratórias. Destaca-se que por terem proximidade com a China e detectarem casos antes que os outros países da amostra, pareceram eficientes e rápidos no agir contra a doença.

A Islândia, a Dinamarca, a Finlândia, a Alemanha e a Noruega estão listados como os melhores países na luta contra o Corona vírus. Coincidentemente, estes cinco países são governados por mulheres e ocupam as primeiras posições entre os 144 do ranking do Relatório Global sobre igualdade de gênero do Fórum Econômico Mundial (FEM). Além de conseguirem frear a doença, apresentam alta escolaridade, redução da disparidade salarial entre homens e mulheres, incentivo à presença feminina nos altos escalões do governo e das empresas e garantia de licenças maternidade e paternidade compartilhadas e remuneradas são algumas das iniciativas comuns a essas nações (BERTOLDO, 2020).

O sucesso desses países e dessas lideranças femininas durante a pandemia se deve a uma característica apontada por especialistas: as mulheres se dedicam mais aos cuidados com seus próximos do que os homens, o que não tem a ver com nossos genes e sim com uma construção social histórica. As líderes que se destacaram representam democracias parlamentares, onde os governos propiciam uma resposta rápida para problemas, seja qual for a razão, a constatação do sucesso feminino representa mais um aprendizado trazido pela pandemia (PURCHIO, 2020).

Assim, o artigo corrobora os achados de Coscieme et al. (2020) em que alguns países apresentaram mais sucesso do que outros no tratamento da pandemia da COVID-19. Quando exploradas as diferentes abordagens políticas adotadas, bem como os fatores socioeconômicos subjacentes, se nota um interessante conjunto de correlações: em países liderados por mulheres o desempenho é significativamente melhor do que aqueles liderados por homens em uma ampla gama de dimensões relativas à saúde global crise.

As conclusões acerca da temática abordada no presente estudo, se confirmam também com os resultados de Sergent e Stajkovic (2020) que estudaram os estados dos EUA, e concluíram que o sexo do governador interferiu nas ordens de isolamento antecipadas. Além disso, estados com governadoras que emitiram ordens de confinamento precocemente apresentaram número menor de mortes em comparação com estados com governadores que fizeram o mesmo. $O$ estudo ainda mostra que em comparação com os homens governantes, as governadoras expressaram mais empatia e confiança em suas instruções.

Finalmente, se aponta a contribuição dessa pesquisa; a possibilidade de estimular a reflexão acerca da falta de equidade em diferentes segmentos da sociedade entre homens e mulheres que é a primeira etapa para que rompam com o paradigma da supremacia masculina nas diferentes esferas da sociedade.

\section{REFERÊNCIAS}

ANDERSON, R. M.; HEESTERBEEK, H.; KLINKENBERG, D.; HOLLINGSWORTH, T. D. How will country-based mitigation measures influence the course of the COVID-19 epidemic? The Lancet, v. 395, n. 10228, p. 931-934, 2020. DOI: https://doi.org/10.1016/S0140-

6736(20)30567-5.

RGO - Revista Gestão Organizacional, Chapecó, v. 14, n. 1, p. 390-415, jan./abr. 2021. 
ATKESON, L. R.; CARRILLO, N. More is Better: The Influence of Collective Female Descriptive Representation on External Efficacy. Politics and Gender, v. 3, n. 1, p. 79-101, 2007. DOI: https://doi.org/10.1017/S1743923X0707002X.

BAHN, KATE; COHEN, JENNIFER; VAN DER MEULEN RODGERS, Y. A Feminist Perspective on COVID-19 and the Value of Care Work Globally. Gender, Work \& Organization, 2020. DOI: https://doi.org/10.1111/gwao.12459.

BARTZ, C.; CRESWELL, B. J. How Suit It Isn't: A Dearth of Female Bosses. The New York Times, 2006. Disponível em: https://www.nytimes.com/2006/12/17/business/yourmoney/17csuite.html. Acesso em: 2 jul. 2020.

BBC. Coronavirus and South Korea: How lives changed to beat the virus. BBC News, n. Abr. 2020, 2020a. Disponível em: https://www.bbc.com/news/world-asia-52482553. Acesso em: 3 jul. 2020.

BBC. Coronavirus: Czechs free to move again 24. BBC News, n. Abr. 2020, 2020b. Disponível em: https://www.bbc.com/news/world-europe-52411989. Acesso em: 2 jul. 2020.

BBC. Coronavírus : novos mínimos de mortes na França , Espanha e Itália. BBC News, 2020c. Disponível em: https://observador.pt/2020/05/10/covid-19-numero-de-mortes-em-italiafranca-reino-unido-e-espanha-em-minimos-de-mais-de-um-mes/. Acesso em: 13 jul. 2020.

BBC. Coronavírus : O que diz o modelo matemático que levou o Reino Unido a mudar radicalmente combate à Covid-19 Medição feita pelo Imperial College de Londres mostrou um panorama muito desolador se o Reino Unido e os Estados Unidos. G1, 2020d. Disponível em: https://g1.globo.com/bemestar/coronavirus/noticia/2020/03/19/coronavirus-o-quediz-o-modelo-matematico-que-levou-o-reino-unido-a-mudar-radicalmente-combate-a-covid19.ghtml. Acesso em: 12 jul. 2020.

$B B C$. Coronavírus : Por que milhares de israelenses foram às ruas protestar em meio à pandemia de covid-19. BBC News, 12 jul. 2020e. Disponível em: https://www.bbc.com/portuguese/internacional-53381030. Acesso em: 12 jul. 2020.

BERTOLDO, S. Eficientes contra o coronavírus , países governados por mulheres se destacam em políticas de igualdade de gênero. Gênero e Número, p. 1-7, 2020.

BONIS, G. Como a Alemanha avança para conter o novo coronavírus e salvar vidas. BBC News, 28 mar. 2020. Disponível em: https://www.bbc.com/portuguese/internacional52040181\#: :text=A\%20Alemanha\%20vem\%20conseguido\%20identificar,espalhem\%20aind a\%20mais\%20o\%20v\%C3\%ADrus. Acesso em: 20 jul. 2020.

CERIBELI, H. B.; ROCHA, G. B. DE S.; PEREIRA, M. R. Mulheres em cargos de chefia: desafios e percepções. Diálogo, v. 2014, n. 36, p. 1-16, 2017. DOI:

http://dx.doi.org/10.18316/dialogo.v0i36.3738. 
CHARUMATHI, B.; RAHMAN, H. Do women on boards influence climate change disclosures to CDP? - Evidence from large indian companies. Australasian Accounting, Business and Finance Journal, v. 13, n. 2, p. 5-31, 2019. DOI: 10.14453/aabfj.v13i2.2.

CORNWALL, A. Women's empowerment: What works? Journal of International

Development, v. 168, n. 10-13, p. 1-30, 2016. DOI: https://doi.org/10.1002/jid.3210.

COSCIEME, L. et al. Women in power: Female leadership and public health outcomes during the COVID-19 pandemic. medRxiv, p. 1-22, 2020. DOI:

https://doi.org/10.1101/2020.07.13.20152397.

CUNHA, A. C. C.; SPANHOL, C. D. Liderança Feminina: Características E Importância À Identidade Da Mulher. Revista Científica da Faculdade Antonio Meneghetti, p. 91-114, 2014. DOI: https://doi.org/10.18815/sh.2014v4n5.54.

DAVIES, C. What measures are UK ministers considering to curb second wave of Covid19? 2020. The Guardian. Disponível em:

https://www.theguardian.com/world/2020/sep/20/measures-uk-ministers-are-consideringto-curb-second-wave-of-covid-19. Acesso em: 10 nov. 2020.

DELANO. How Luxembourg is Preparing for a Second Wave. 2020. Disponível em: https://delano.lu/d/detail/news/how-luxembourg-preparing-second-wave/210540. Acesso em: 18 nov. 2020.

DOLLAR, D.; FISMAN, R.; GATTI, R. Are women really the "fairer" sex? Corruption and women in government. Journal of Economic Behavior and Organization, v. 46, n. 4, p. 423-429, 2001. DOI: https://doi.org/10.1016/S0167-2681(01)00169-X.

DU, L.; HUANG, G. Japan May Have Beaten Coronavirus Without Lockdowns or Mass Testing. But How? Time, 2020. Disponível em: https://time.com/5842139/japan-beat-coronavirustesting-lockdowns/. Acesso em: 20 jul. 2020.

EXAME, R. A Nova Zelância venceu o coronavírus - e tem 3 lições para o Brasil. Revista Exame, v. 8, n. 14, p. 225-241, 5 maio 2020. Disponível em: https://exame.com/mundo/anova-zelandia-venceu-o-coronavirus-e-tem-3-licoes-para-o-brasil-2/. Acesso em: 1 jun. 2020.

FARIZA, I. Coronavírus joga sal sobre a ferida da desigualdade e aumenta a diferença econômica. El País, 2020. Disponível em: https://brasil.elpais.com/economia/2020-0601/coronavirus-joga-sal-sobre-a-ferida-da-desigualdade-e-aumenta-a-diferencaeconomica.html. Acesso em: 1 jun. 2020.

FARR, C. How Canada is fighting Covid-19 : Ramping up PPE production , travel ban from the U. S. and. CNBC, 2020. Disponível em: https://www.cnbc.com/2020/07/13/how-canada-isfighting-covid-19-ppe-travel-ban-bonnie-henry.html. Acesso em: 20 jun. 2020.

FARRER, M. New Zealand's Covid-19 response the best in the world, say global business 
leaders. The Guardian. 2020. Disponível em: https://www.theguardian.com/world/2020/oct/08/new-zealands-covid-19-response-thebest-in-the-world-say-global-business-leaders. Acesso em: 8 nov. 2020.

FOREIGN, O. Foreign travel advice Liechtenstein. Disponível em: https://www.gov.uk/foreign-travel-advice/liechtenstein/coronavirus. Acesso em: 20 jun. 2020.

FOSTER, M.; KREVER, M. Iceland now feels like the coronavirus never happened. CNN Travel, n. Jun., 2020. Disponível em: https://edition.cnn.com/travel/article/iceland-reopenscoronavirus/index.html. Acesso em: 6 jul. 2020.

GAVIN LEE. Coronavirus: Why so many people are dying in Belgium. BBC, n. Maio 2020, 2020. Disponível em: https://www.bbc.com/news/world-europe-52491210. Acesso em: 13 jun. 2020.

GT. US, Brazil most "failed” COVID-19 states. Global Times, v. 21, n. 1, p. 1-9, 2020. Disponível em: https://www.globaltimes.cn/content/1192770.shtml. Acesso em: 12 jul.2020.

GUNYA, A. Coronavirus Is Surging All Over Asia and the Pacific. Here's What the Rest of the World Can Learn. 2020. Time. Disponível em: https://time.com/5866156/coronavirus-surgeasia-lessons/. Acesso em: 10 out. 2020.

JONES, A. A volta do coronavírus a Singapura, país que era 'exemplo ' no combate à doença. G1, 12 abr. 2020. Disponível em: https://g1.globo.com/bemestar/coronavirus/noticia/2020/04/12/a-volta-do-coronavirus-asingapura-pais-que-era-exemplo-no-combate-a-doenca.ghtml. Acesso em: 10 jul. 2020.

JONNES, A. When did New Zealand bring in border closures ? BBC, 10 jul. 2020. Disponível em: https://www.bbc.com/news/world-asia-

53274085\#: :text=When\%20did\%20New\%20Zealand\%20bring,coming\%20from\%20or\%20vi a\%20China. Acesso em: 15 jul. 2020.

LIMA, J., MIRANDA, C., \& CASA NOVA, S. Auditoria é coisa de mulher? Percepção de diferenças entre profissionais. In: Congresso Unb de Contabilidade, 2018. Anais eletrônicos do Congresso UnB de Contabilidade e Governança, Brasília, UnB, 2018. Disponível em: https://conferencias.unb.br/index.php/ccgunb/4CCGUnB/paper/viewPDFInterstitial/11329/ 2197. Acesso em: 01 jun. 2020.

LEE, Y. N. As countries consider lifting lockdowns, some in Asia are experiencing a resurgence in coronavirus cases. 2020. CNBC. Disponível em: https://www.cnbc.com/2020/05/12/coronavirus-some-asian-countries-see-second-waveresurgence-in-cases.html. Acesso em: 3 nov. 2020.

MCLAREN, H. J.; WONG, K. R.; NGUYEN, K. N.; MAHAMADACHCHI, K. N. D. Covid-19 and women's triple burden: Vignettes from Sri Lanka, Malaysia, Vietnam and Australia. Social Sciences, v. 9, n. 5, 2020. DOI: https://doi.org/10.3390/socsci9050087 
MEAGHER, K.; SINGH, N. S.; PATEL, P. The role of gender inclusive leadership during the COVID-19 pandemic to support vulnerable populations in conflict settings. BMJ Global Health, v. 5, n. 9, p. 1-4, 2020. DOI: http://dx.doi.org/10.1136/bmjgh-2020-003760

MILLER, A. Why a 2nd wave of COVID-19 is more dangerous than it looks. 2020. CBC. Disponível em: https://www.cbc.ca/news/health/coronavirus-canada-second-wavelockdown-1.5748106. Acesso em: 5 nov. 2020.

NACIONAL, J. Coronavírus : Finlândia é um dos países mais bem preparados do mundo para combater pandemia. G1, 14 abr. 2020.

NEGÓCIOS, É. As medidas da Noruega para conter os impactos economicos e a disseminação do coronavírus. Época Negócios, 17 mar. 2020.

NOVA, S. P. DE C. C. Impactos de mestrados especiais em contabilidade na trajetória de seus egressos: um olhar especial para gênero. Revista de Contabilidade e Controladoria, p. 3762, 2012. DOI: http://dx.doi.org/10.5380/rcc.v4i3.29952

NOVELLI, V. Austrália reduz curva de contágio graças a governadores. Veja, 31 mar. 2020. Disponível em: https://veja.abril.com.br/mundo/australia-reduz-curva-de-contagio-gracas-agovernadores/. Acesso em: 2 jun. 2020.

ORGANIZAÇÃO PARA A COOPERAÇÃO E DESENVOLVIMENTO ECONÔMICO (OECD). Women at the core of the fight against COVID-19. 2020. Disponível em: https://read.oecdilibrary.org/view/?ref=127_127000-awfnqj80me\&title=Women-at-the-core-of-the-fightagainst-COVID-19-crisis. Acesso em: 10 nov. 2020.

ORGANIZAÇÃO PAN-AMERICANA DE SAÚDE (OPAS). Folha informativa COVID-19 - Escritório da OPAS e da OMS no Brasil. Principais Informações de 20 de novembro de 2020. 2020. Disponível em: https://www.paho.org/pt/covid19. Acesso em: 23 nov. 2020.

OLAGNIER, D.; MOGENSEN, T. H. The Covid-19 pandemic in Denmark: Big lessons from a small country. Cytokine and Growth Factor Reviews, p. 10-12, 2020. DOI: https://doi.org/10.1016/j.cytogfr.2020.05.005.

ORGANIZAÇÃO PAN-AMERICANA DE SAÚDE. INDICADORES DE SAÚDE: Elementos Conceituais e Práticos. Indicadores de Saúde: Elementos Conceituais e Práticos, n. Capítulo 2, p. 2-6, 2020.

PAZ, C. DE.; MULLER, M.; BOUDET, A. M. M. Gender dimensions of the COVID-19 pandemic. World Bank Group - Gender, v. 18, n. Abr., p. 964-969, 2020. Disponível em: http://hdl.handle.net/10986/33622. Acesso em: 2 jun. 2020.

PESSOA, F. E. N.; MAIA, A. J. R.; FAÇANHA, M. C.; GUIMARÃES, D. B.; REBOUÇAS, S. M. D. P. Determinantes Da Diversidade De Gênero Das Empresas Do Brics. Revista Gestão Organizacional, v. 13, n. 3, p. 162-183, 2020. DOI: https://doi.org/10.22277/rgo.v13i3.4961. 
PIAZZA, K. S.; DIAZ, G. Light in the midst of chaos: COVID-19 and female politicalrepresentation. World Development. v. 136, 2020. Doi:

https://doi.org/10.1016/j.worlddev.2020.105125.

POINTS, K. Europe Versus Coronavirus - Austria and the Road to a " New Normal ". Disponível em: https://www.institutmontaigne.org/en/blog/europe-versus-coronavirusaustria-and-road-new-normal. Acesso em: 8 maio. 2020.

PURCHIO, L. Elas vencem a Covid-19. ISTOÉ, 2020. Disponível em: https://istoe.com.br/elasvencem-a-covid-19/. Acesso em: 12 jul. 2020.

QUEIROZ, P. R. C. A pandemia, o home office e o trabalho das mulheres. Universidade Federal da Integração Latino-Americana Boletim do Centro Interdisciplinar de Letras e Artes - CILA, v. 2, n. 1, 2020.

RFI. Eslovênia é primeiro país da Europa a declarar fim da epidemia de coronavírus. G1, 2020a. Disponível em:

https://g1.globo.com/bemestar/coronavirus/noticia/2020/05/15/eslovenia-e-primeiro-paisda-europa-a-declarar-fim-da-epidemia-de-coronavirus.ghtml. Acesso em: 5 jun. 2020.

RFI. Suíça tem aumento de casos de Covid-19 e é criticada por suspender quarentena cedo demais. G1, 21 jun. 2020b. Disponível em:

https://g1.globo.com/mundo/noticia/2020/06/21/suica-tem-aumento-de-casos-de-covid19-e-e-criticada-por-suspender-quarentena-cedo-demais.ghtml. Acesso em: 1 jul. 2020.

RODRIGUES, M. S. L. M. A representatividade das mulheres na liderança de topo: Análise das atuais empresas do PSI-20 (2005-2016). 2017. Dissertação (Mestrado em Economia e Administração de Empresas) - Faculdade de Economia, Universidade do Porto: Porto, 2017.

SAIIDI, U. How Hong Kong beat coronavirus and avoided lockdown. CNBC, 2 jul. 2020. Disponível em: https://www.cnbc.com/2020/07/03/how-hong-kong-beat-coronavirus-andavoided-lockdown.html. Acesso em: 1 ago. 2020.

SAVAGE, M. Did Sweden's coronavirus strategy succeed or fail? BBC News, jun. 2020. Disponível em: https://www.bbc.com/news/world-europe-

53498133\#: :text=But\%20according\%20to\%20clinical\%20epidemiologist,as\%20a\%20whole \%20has\%20failed. Acesso em: 20 ago. 2020.

SERGENT, K.; STAJKOVIC, A. D. Women's leadership is associated with fewer deaths during the COVID-19 crisis: Quantitative and qualitative analyses of United States governors.

Journal of Applied Psychology, v. 105, n. 8, p. 771-783, 2020. DOI:

http://dx.doi.org/10.1037/apl0000577.

SHARLAND, L. Advancing gender equality and global security: Navigating the disruption of Covid-19. After Covid-19, v. 1, n. maio, p. 93, 2020.

SILASKOVA, J.; TAKAHASHI, M. A Estônia construiu uma das sociedades digitais mais 
avançadas do mundo . Durante o COVID-19, isso se tornou uma tábua de salvação. WE FORUM. Disponível em: https://www.weforum.org/agenda/2020/07/estonia-advanceddigital-society-here-s-how-that-helped-it-during-covid-19/. Acesso em: 1 jul. 2020.

SILVA, A. L. C.; MARGEM, H. Mulheres em cargos de alta administração afetam o valor e desempenho das empresas brasileiras? Revista Brasileira Finanças, v. 13, n. 1, p. 102-133, 2015. DOI: https://doi.org/10.12660/rbfin.v13n1.2015.35116.

THE GUARDIAN. Covid in Europe: how countries are tackling second wave. 2020. Disponível em: https://www.theguardian.com/world/2020/oct/15/covid-in-europe-how-countries-aretackling-second-wave. Acesso em: 15 nov. 2020.

TUGWELL, P.; NIKAS, S. Gregos mostram ao mundo como combater surto de covid-19. Valor Econômico, 17 abr. 2020. Disponível em:

<https://valor.globo.com/mundo/noticia/2020/04/17/gregos-mostram-ao-mundo-comocombater-surto-de-covid-19.ghtml. Acesso em: 30 de jul. 2020.

UCHOA, P. Coronavírus: por que países liderados por mulheres se destacam no combate à pandemia? BBC. 2020 Disponível em: https://www.bbc.com/portuguese/internacional52376867 Acesso em: 15 jul. 2020.

VENAGLIA, G. Brasil passa Rússia e é segundo país com mais casos de Covid- no mundo. CNN Brasil, Disponível em: https://www.cnnbrasil.com.br/saude/2020/05/22/brasil-passa-russiae-e-segundo-pais-com-mais-casos-de-covid-19-no-mundo. Acesso em: 22 maio 2020.

WALKER, J. Luxembourg: the little-known Covid-19 hotbed. New Statesman, Disponível em: https://www.newstatesman.com/world/europe/2020/03/luxembourg-coronavirus-covid19-cases-testing-crossborder. Acesso em: 23 mar. 2020.

YEUNG, J. Two weeks of zero local infections: How Hong Kong contained its second wave of covid-19. How Hong Kong contained its second wave of Covid-19. 2020. CNN. Disponível em: https://edition.cnn.com/2020/05/05/asia/hong-kong-coronavirus-recovery-intlhnk/index.html. Acesso em: 1 jul. 2020. 